\title{
Article \\ Inclusively Recognizing Faculty Innovation and Entrepreneurship Impact within Promotion and Tenure Considerations
}

\author{
Jana Bouwma-Gearhart ${ }^{1, *}$, Cindy Lenhart ${ }^{1}$, Rich Carter ${ }^{2}{ }^{\circledR}$, Karl Mundorff $^{3}$, Holly Cho $^{4}$ and Jessica Knoch ${ }^{1}$ \\ 1 College of Education, Oregon State University, Corvallis, OR 97331, USA; \\ cindy.lenhart@oregonstate.edu (C.L.); jessica.knoch@oregonstate.edu (J.K.) \\ 2 Department of Chemistry \& Research Office, Oregon State University, Corvallis, OR 97331, USA; \\ rich.carter@oregonstate.edu \\ 3 Research Office, Oregon State University, Corvallis, OR 97331, USA; karl.mundorff@oregonstate.edu \\ 4 STEM Research Center, Oregon State University, Corvallis, OR 97331, USA; Holly.cho@oregonstate.edu \\ * Correspondence: Jana.Bouwma-Gearhart@oregonstate.edu
}

Citation: Bouwma-Gearhart, J.;

Lenhart, C.; Carter, R.; Mundorff, K.; Cho, H.; Knoch, J. Inclusively Recognizing Faculty Innovation and Entrepreneurship Impact within Promotion and Tenure

Considerations. J. Open Innov. Technol. Mark. Complex. 2021, 7, 182. https:// doi.org/10.3390/joitmc7030182

Received: 16 June 2021

Accepted: 29 July 2021

Published: 4 August 2021

Publisher's Note: MDPI stays neutra with regard to jurisdictional claims in published maps and institutional affiliations.

Copyright: (c) 2021 by the authors. Licensee MDPI, Basel, Switzerland. This article is an open access article distributed under the terms and conditions of the Creative Commons Attribution (CC BY) license (https:// creativecommons.org/licenses/by/ $4.0 /)$
Abstract: Academic research has led to a plethora of innovations and entrepreneurial resources (I\&E), allowing for enhancements to the greater good. Institutions of higher education have recognized the value of faculty (and student) I\&E in mission statements and strategic plans, including developing students' skills, thinking, and employability. Yet commensurate promotion and tenure processes and policies are not a certainty. We describe (1) mapping the unknown terrain of factors relevant to the evaluation of tenure-line faculty members' I\&E in United States promotion considerations, and related training for students via a survey of 99 diverse institutions, and (2) recommendations that inform an alliance of $67+$ US institutions pursuing best practices for recognizing faculty I\&E impact through reward structures.

Keywords: faculty innovation; entrepreneurship; promotion; tenure; higher education

\section{Introduction}

As university-based researchers raced to contribute knowledge for the worldwide response to COVID-19, we were reminded of how faculty research (including that starting as basic science) has led to a plethora of innovations, methods, services, or technologies with potential to enhance the social good [1], considering ever-evolving needs [2]. Faculty research is one way that institutions of higher education serve the greater public. Research also enhances the educational experiences of students, arguably the main beneficiary of education systems. As benefactors, faculty also reap rewards of their scholarly endeavors in the form of salary and professional advancement, promotion, and (potentially) tenure (which equates to security of employment in the United States of America). Awarding of promotion and tenure extends beyond faculty research, often also including assessment of their accomplishments as educators, providers of service and outreach, and (at times) their leadership and administration.

\subsection{Norms around Faculty Promotion and Tenure}

Faculty promotion and tenure (hereafter $P \mathcal{E} T$ ) processes operate as a central "motivational and cultural force in the academic lives" of faculty members [3]. Factors that influence promotion and tenure considerations vary widely depending on the type of institution, from private liberal arts colleges to major research universities. There are commonalities, however, which include time frame (i.e., generally a certain number of years after hire or last promotion), principal actors involved (e.g., department chair, dean or provost, president, external reviewers), and a review of the candidate's performance across common work categories (e.g., teaching and research). Yet the organizational contexts in which faculty are situated also matter significantly to faculty P\&T. Factors include the 
type of institution and its priorities, that influence efforts and considerations around the relative importance of research versus teaching and prioritizations of service and outreach versus those two activities [4]. The influence of academic disciplines on P\&T processes, within the context of institutional values, aspirations, privileges, and power structures, are also significant [5]. Academic disciplines are "the tools, methods, procedures, examples, concepts, and theories that account coherently for a set of objects or subjects" [6]. Specifically, academic disciplines "reflect professional expectations, measures of productivity, and standards for tenure and promotion," driving normative guidelines (e.g., career pathways and publishing expectations) that influence the criteria used to evaluate performance [7].

Adding to the complexity impacting P\&T outcomes are the constructs of and realities around individuals' social identities. The US Department of Education, in 2020 [8], noted that, since 1993, white, male faculty have been disproportionately tenured and promoted in comparison to other groups of faculty. Recent research confirms this pattern across academia. In a study of four large, research extensive, land grant universities, Durodoye et al. [7] found that faculty identifying as female, in comparison to male, were more prone to leave without tenure and less likely to be promoted to associate or full professor. This held true across all academic disciplines. In comparison, they found that promotion and tenure for faculty identifying as a race or ethnicity other than white were mixed, with faculty of color less likely to be promoted to full professor within disciplines such as business, education, health, and veterinary sciences, but no difference between racial groups in promotions and tenure in disciplines such as agricultural sciences and natural resources, engineering, biological and biomedical sciences, physical and mathematical sciences, or social sciences. They also found that promotion and tenure processes were different across the disciplines and departmental structures, which added a layer of complexity to understanding how institutions were addressing promotion and tenure considerations [7]. In another study, involving five social and natural sciences departments at a large research extensive university, researchers found white, male faculty spent a disproportionate amount of their time on activities that "counted" toward promotion and tenure, while women, faculty of color, queer faculty, and faculty from working class background spent more time on performing service and other activities that were less valued (e.g., teaching, advising marginalized students). The underrepresented groups did not attain promotion and tenure at the same level as their white, male counterparts, partially per a mismatch between the reviewers of the cases (i.e., predominantly white males) [9].

Indeed, P\&T processes are part of the reason that universities have not adequately combatted the systemic issues of underrepresentation in academia, regardless of the highly visible priorities to diversify the professoriate at many colleges and universities $[7,10]$. The reasons for this are somewhat insidious. Institutions of higher education, and academia writ large are built on meritocratic assumptions, equating success with hard work, [11] and failing to recognize the role that systems of power or oppression play in influencing resources and opportunities [12]. As well, women, faculty of color, and other underrepresented groups may face two sets of rules when applying for reappointment, promotion, and tenure, rules that are made explicit in handbooks and policy documents and those that operate beneath the surface [10]. Implicit processes include unspoken rules around quality of research or the importance (or not) of teaching and mentoring. These rules thus disproportionately affect groups of faculty who are claimed as helping to "diversify" academic departments via their presence and their support of others. These groups of faculty continue to face P\&T-related expectations and requirements set by tenured colleagues and administrators "off the hook" to do such work $[4,13,14]$. An incongruity between how faculty actually spend their time versus what is considered in their evaluation results for the underrepresented faculty, while those assessing and rewarding P\&T, largely white males, are further available to obtain work more valued in P\&T review, including research [15]. There are many reasons for concern with P\&T structures and processes that do not adequately reward teaching and mentoring. 


\subsection{Pathways to a More Efficacious and Equitable PET System in Academia}

Any changes to $\mathrm{P} \& \mathrm{~T}$ structures and processes will require fairly robust lifts to change the intersection of multiple phenomena within and between academic organizations [16]. These phenomena include cultural norms and how they influence, and are influenced by, organizational structures and processes. Mendoza et al. [17] conceptualized academia as a cultural field, where "norms determine legitimacy" (p. 1475), that of an academics' work and, by proxy, the academics themselves. The professional work of academics (those that work in the institutions of academia toward discovering or making other advancements in knowledge) is highly specialized, requiring other peer specialists to judge its worth, typically afforded by work being distributed via prestigious outlets (e.g., journals or conferences) or other rewards concerning the merit of professionals' ideas (e.g., external funding of future research projects); these outlets themselves are the product of peer review.

Many readers of this journal can envision a P\&T "packet" from the tenure-line of postsecondary faculty - a personal statement, the detailed CV or dossier, perhaps representative work products such as key publications. With an accompanying cover letter detailing context-specific norms, the faculty member's organization (department, college, or institution) attempts to frame the faculty member's reality for evaluation by subject matter experts. These experts are both internal to the faculty member's institutionally based organizations (e.g., departments or college) and external. For certain faculty, "external" experts work at their institution but in another department or college. For faculty with significant research responsibilities, these experts include those external to the candidate's institution. Regardless of where these experts sit, and of the cover letter writer's attempt to frame what professional success resembles for the faculty candidate, we know that reviewers apply their own value systems in their reviews, informed by cultural norms $[5,18]$ around all facets of faculty work, including research, teaching, and service $[19,20]$. An interpersonal and organizational linkage of value systems can inhibit fair review of faculty, as well as inhibit any attempted adjustments to P\&T-related processes and structures intended to better attend to faculty realities $[5,21]$. Although the reviewers' privileging across the various tasks that faculty engage in are influenced by type of institution and discipline, common metrics used for tenure-line faculty are the amount of publications and amount of external funding [22-25].

The shared value systems of academics can be seen as the linchpin in attempts to revise the larger system of processes and structures involved in the evaluation of academics' work. This potential is due, in part, to the phenomena of isomorphism, which explains and predicts how organizations respond to external pressures and, often, begin to resemble others. DiMaggio \& Powell [26] detailed institutional isomorphism across three mechanisms that can allow institutions to become more similar in processes and structures to others in the same field (such as those in higher education), defined as those with similar goals and related strategies [27]. Coercive isomorphism results from formal and informal pressures exerted on organizations by other organizations that they depend on (e.g., university accrediting bodies) or by cultural expectations within the social structures within which the organization operates (e.g., a country's higher education system). Normative pressures stem primarily from two aspects of professionalism, (1) standards dictating and accounting for certain formal educational programming and the resulting discipline-specific knowledge and expertise (e.g., conferring of licenses and degrees), and (2) professional networks of these experts that span organizations and allow discipline-specific diffusing of information between them (e.g., those united by disciplinary societies or academic journals). Mimetic isomorphism occurs when organizations are uncertain or ambiguous around their goals and, thus, imitate, adapt, or standardize their practices with other organizations they deem legitimate to establish and evolve the organization. Power is an important component of isomorphism, with certain organizations holding more sway with others per their perceived authority and legitimacy in relevant social structures. Powerful organizations (real or perceived) are often emulated. 
Responding to and copying other external organizations can result in normalization across organizations and can hinder innovation. The effects of isomorphism can be both negative and positive from the perspective of an organization, those that comprise it, and those it serves. Arguably, more positive change can be inspired by more powerful organizations that, for instance, promote more humanistic practices and policies or that better support diverse faculty to be successful. No doubt, we are in a moment where institutions of higher education are anxiously trying to learn from each other's successes and mistakes as they respond to the societal devastation due to the COVID-19 pandemic.

Thus, isomorphism affords both normalization as well as innovation. The mechanisms of isomorphism are active processes, with organizations modifying or adapting models to suit their particular needs or situation. Isomorphism can serve both sides of the survival coin for institutions of higher education, allowing them to be both "an integrated part of a growing, and highly interconnected, internationalized, and standardized higher education "industry" via "standardization", as well as innovative enough to be unique enough in mission to not be too redundant" [26], p. 473. To understand how requires viewing change and stability not as a dichotomy but as seeing an organization's concurrent attention to both. Stensaker and Norgård [28] call this an identity formation process (475), as organizations continuously reimagine and create (often slight) changes to processes and structures (e.g., evidence utilized in their promotion and tenure systems) important to maintaining their identity among peers and their internal constituents. These changes are often motivated by new ideas to organizations and their individuals, with an idea's power somewhat dependent on the who, how, and when of their presentation, aligned with rules and power structures relevant to the organization and others in their field [29]. Ideas are consumed as practices or structures, in ways appropriate to an organization's identity or as a challenging or modifying element to that organization's identity.

\subsection{Recognizing Innovation and Entrepreneurship (IEE) as a Scholarly Path}

Institutional isomorphism is an important assumption around the focus of this paper, by that being problematizing P\&T-related structures and processes and the array of faculty work they privilege. Along with the concerns of P\&T structures and processes at times, and not adequately rewarding teaching and mentoring, there is also concern for the alsodevalued faculty members' interdisciplinary and teamwork, community engagement, and public scholarship, and diversity, equity and inclusion (DEI) work [3,5,30]. As have others, we argue that rewarding such activities can both help universities to adequately benefit society and support a more diverse 21st-century professoriate. To this list, we also add the faculty activities of innovation and entrepreneurship.

The collective innovation and entrepreneurship (hereafter IEE) of faculty members at institutions of higher education has vast potential for positive societal impacts worldwide. Including work resulting in copyrights and patents, impactful faculty I\&E goes well beyond technology. Many faculty-generated innovations have little to no immediate market potential, for instance, the development of culturally appropriate technologies for cleaner cooking or filtering water with community stakeholders [31]. Still, recognizing the benefits of such work, faculty and academic administrators have become key actors in the neoliberal state, contributing their research products or discoveries to the market [17,32].

Over time, institutions of higher education seem to have recognized the value of various types and impacts of faculty I\&E, as reflected in reshaped mission statements and strategic plans [18,33]. A corresponding commitment to academic capitalism [32] can position new research findings as knowledge of value to the larger society, including the private sector for commercialization [34]. The recent bipartisan, bicameral United States Innovation and Competition Act of 2021 was passed this last June, expanding the National Science Foundation's efforts to increase research spending at universities to drive investments in the discovery, creation, and commercialization of technology fields of the future. The activities funded by this act are key to advancing US progress in key technology areas, including the creation of focused research centers, manufacturing revival, and jumpstarting 
local communities. As the US works to improve its distinctive innovation ecosystems, other nations are replicating and improving on its historical structural advantages.

I\&E are the engines of economic growth, a key to national security, and the driver of long-term improvements in living standards and solutions for humankind's greatest challenges. Besides enhancing the public good and economies, faculty I\&E enhances the image, and fundraising capacities of institutions of higher education, the recruitment of faculty, and the retention of diverse personnel $[17,18,35,36]$. Faculty members benefit professionally from their I\&E work. Resulting publications and presentations enhance faculty competitiveness for external funding of their subsequent activities, as do patents and commercialization activities. Faculty engagement with funders and industry is correlated with gains in research productivity, work citations, and prestige [18,35-37]. While evidence is sparse, I\&E activity may provide alternate advancement pathways and act as a democratizing process that can influence more equitable outcomes across faculty groups and in P\&T considerations [38].

Conversely, without deliberate attention to best serve all potential innovators, particularly those belonging to marginalized groups in this space, any new efforts to change the value placed on I\&E in P\&T can also replicate the inequities that prevent participation and advancement of diverse faculty; this, in turn, can have harmful economic effects as economists have estimated that US GDP may be 3-4 percent higher with the greater inclusion of women and underrepresented minorities in the innovation process [39-45]. In studies, McKinsey [46] showed that gender and ethnic diversity on companies' executive teams are clearly correlated with higher profitability, by $21 \%$ for gender diversity and $33 \%$ for ethnic and cultural diversity [46]. A lack of diversity in STEM poses a threat to solving global grand challenges and US national security. These statistics indicate a compelling case for pursuit of a more even distribution in I\&E engagement across STEM faculty groups. In 2020, the Council on Competitiveness, National Commission on Innovation and Competitiveness argued that federal, state, and local leadership and strategies are needed to invest in the innovation capacity of those underrepresented in the US innovation landscape, with the ultimate goal of increasing their participation ten-fold [45].

Faculty I\&E work also supports students' career preparation and aspirations. Beyond providing financial support for student researchers, faculty engaged in I\&E activities can develop and offer educational programming through which students can develop collaboration, communication, and marketing skills [47] and design thinking [48]. The interdisciplinary and "soft" skills (e.g., communication skills and creativity) promoted by I\&E work help students learn to contribute to solving local and global challenges [47,49-52]. From an economic development standpoint, startups (one of many results of faculty I\&E) are disproportionately responsible for job growth [53] and can be an excellent way to ensure a career for those graduate students who will not be entering academia and yet are instrumental to the commercialization efforts [54]. Graduates exposed to I\&E activities during postsecondary education may better compete for workforce positions, including private-sector jobs, which those having earned doctorates are currently more likely to secure over jobs in public-service domains, including academia [55]. Over the last two decades, certain STEM fields (life, health, computer, and mathematical sciences) have seen a $10-16 \%$ decrease in tenure-line positions in academia, with an increase of students entering other sectors with I\&E as their cornerstone [56]. Students trained in I\&E work may better direct their careers and demonstrate career resiliency $[18,35,57]$. Yet we, overall, know little about the training of students in I\&E.

\subsection{The (De)valuing of Faculty Innovation and Entrepreneurialism in Promotion and Tenure Considerations}

As a response to research, and push from federal and state levels, universities have implemented a wide variety of I\&E support mechanisms for faculty, including (1) ideation workshops, (2) commercialization grant support, (3) patent searches and filings, (4) licenses and industry contracting, (5) pre-accelerator and accelerator innovation and entrepreneurial 
training programming, (6) incubation space for startup teams, (7) pre-seed and seed funding, (8) shared use equipment and labs, and (9) facilitated connections to industry contacts.

Despite the various social and industrial structures promoting academic capitalism toward economic growth and competitiveness [58], and the positive impacts of faculty I\&E, there is reason to suspect that such work is still devalued in academia. The norms of academia, what Etzkowitz and Leydesdorff [59] call rules and regulations, including teaching and training, may influence this. For instance, "purer" forms and goals of inquiry may continue to be privileged, such as basic science performed "for the greater good" $[17,60]$. Specifically, promotion and tenure (P\&T) processes and policies that recognize and reward faculty members' I\&E work are not a given $[18,21,61,62]$, including at research universities where partnerships with industry and community partners may be more assumed [57,63]. Traditional (and somewhat ambiguous) metrics of the impact of faculty research (e.g., publications and federal grant dollars), afforded prestige by a community of experts, may not have evolved to sufficiently evaluate or acknowledge faculty I\&E-focused advances [36,63].

Opportunities for commercialization of faculty discoveries (a newer option for academics, historically) may feel extra problematic for faculty and those evaluating them, who may see a goal of commercialization as counter to serving the public good and as a historical threat to academic freedom $[17,32,64,65]$. While there is emerging research that challenges these concerns (e.g., [66-68]), a shared value system based on these concerns among academics continues to inform their evaluation of their peers' work. Mendoza et al. [17], drawing on the work of Merton [69] and Anderson et al. [60], summarizes this value system as "aligned with the traditional view of scientists who engage in research objectively, autonomously and freely, who share knowledge openly through collegiality, and who do not seek personal advantage but rather advancement of science for the public good" (p. 1475). Disagreement exists among some faculty who assert that academia and academics have "lost sight of" their missions to advance the greater good. Indeed, a large enough community of academics may not yet exist to confer legitimacy of faculty I\&E work across the disciplines, nor at their intersection (where I\&E work is conducted). Relevant, actionable scholarships and innovation require an inclusive body of researchers that have diverse backgrounds, interests, and life experiences to broaden the field and I\&E potential [13].

Thus, it seems that faculty performing or considering innovation-focused and entrepreneurial-minded research, and related student development, risk venturing down P\&T paths based on somewhat antiquated value systems. How real are these concerns currently? Admittedly, research confirming suspicions that the devaluing of faculty I\&E in P\&T review is limited. In 2014, Sanberg et al. [57] demonstrated that most universities around the globe had not evolved P\&T guidelines to consider faculty patents and other indicators of innovation as commercialization. This stood in contradiction to data gathered in both 1994 and again in 2013, demonstrating that university faculty largely approved of counting "use-oriented research" and "patentable inventions" in P\&T considerations. Similarly, a 2015 APLU task force concluded that US institutions of higher education did not reward faculty technology transfer in P\&T considerations [18]. Per these limited findings, it seems US institutions of higher education may inadequately promote faculty I\&E to a degree that can maintain societal demands. (Similar findings have been noted internationally; see Macuare and Kubisen [70].

Still, much of this past research has largely concerned one type of faculty I\&E activity, that being the legal "transfer" of developed technology to another entity (e.g., a business or (non)governmental organization). We know less about how other types of faculty I\&E are considered in P\&T, including faculty members' work with students, or under-serviced communities, both which may initially result in a reduced volume of products often assessed as P\&T metrics [18]. Even when upper administration champions it, institutional reviewers may view such work as less worthy faculty output [5]. And there may be disagreement regarding what faculty I\&E should "count as" - teaching, research, service, broader impact, or other faculty work category $[5,18,36,57]$. This research, coupled with 
complaints of faculty attempting I\&E, have led to national efforts to better support faculty I\&E. These include the National Science Foundation's (NSF) I-Corps program, funding a consortium of institutions to better prepare current and future faculty to engage in activities focused on the broader impacts of research. This includes providing experiential entrepreneurship education to faculty and other structures to reduce the time and risk associated with translating promising ideas and technologies from the laboratory to the marketplace. However, these programs notably target projects and institutions already funded by NSF.

There are hints that even universities with an established innovation-driven culture may struggle in aligning P\&T processes and policies across the institution, college or disciplinary, and department levels, to account for faculty technology transfer [18]. And key differences between university-level and college- and department-level missions, policies, traditions, and practices may create mixed messages to faculty. Units that have not historically embraced such efforts may further discourage faculty I\&E. Dossier reviewers within and between institutions may, together, form a perfect storm of a lack of knowledge and commitment to effectively evaluate faculty I\&E.

And we still lack actionable insight as to why I\&E activity disparities still exist among faculty groups. For instance, less than $4 \%$ of venture capital is awarded to women and less than $1 \%$ to women of color [71]. Research illustrates that culturally formed perceptions and stereotypes about science, technology, engineering, and mathematics (STEM) disciplines generally and entrepreneurship and commercialization specifically are associated with male-typed and masculine activity [72,73]. In their study of successful women in STEM faculty positions, Howe, Juhas, and Herbers [72] found a strong "ick" factor with respect to involving business and commercialization in science, with concerns surfacing about business and industry rendering their science "dirty" or unethical. A meta-analysis [74] of women's' academic entrepreneurship compiled recommendations to close the gender gap. However, the vast majority of articles focused on changes that women faculty should make, and notably ignored contextual and systemic structures and processes, arguably of significant impact on the careers of faculty. While a lack of a pool of STEM women is often claimed as the reason for gender gaps in entrepreneurship, Blume-Kohout's [75] research demonstrates that less than one-quarter of associated gaps may be explained by the gender differences in the distribution of STEM fields. We need a better understanding of potential systemic barriers to faculty I\&E, across an array of contexts.

How can we create a well-informed, nimbler, and more flexible P\&T systems to effectively evaluate faculty I\&E work, accounting for their modern realities, as well as attending to the needs of the institutions and society to which they contribute? The potential of any attempts to transform complex systems relies on firm understandings of those systems, and this holds for inter- and intra-organizational systems involving faculty work and change efforts [21,76-78]. While the literature we have noted above is helpful, the research base concerning our problem of interest is still relatively scant. Notably, the current evaluation of faculty I\&E, broadly conceived, in considerations of P\&T across the diverse higher education landscape, is unknown. Toward a vision for better supporting and rewarding faculty innovation and entrepreneurialism, and related training for students, we recognized first the need to start to map the current terrain.

\section{Methodology}

\subsection{Research Questions}

Given the wide landscape of institutions of higher education-type in the US employing faculty who may engage in I\&E and seek promotion and tenure, and provide review of other faculty members' cases, we pose the following research questions against a diversity of types of US institutions of higher education (e.g., research universities, master's granting, liberal arts institutions):

1. To what extent is faculty members' I\&E activity valued? 
2. To what extent do relevant personnel feel able in evaluating faculty members' I\&E activity in promotion and tenure cases?

3. To what degree is faculty members' I\&E activity a consideration in the evaluation of their work for awarding of promotion and tenure across various institutional organizations (e.g., departments and disciplines)?

a. As reflected in policy?

b. As reflected in practice?

4. What I\&E-related training, for faculty (including for underrepresented groups), postdoctoral researchers, and students, is offered at institutions?

\subsection{Theoretical Frameworks: Value Creation and Human Capital}

Our theoretical framework relies on both value creation and human capital theories, which help justify the need for our study in relation to the need to question and explore current P\&T structures and the better inclusion of I\&E. It allows insight into the system of academia (and relevant cultures, norms, and beliefs) that privileges certain types of work and workers, per important goals (e.g., educating students, contributing to the solving of societal problems). The framework also illuminates why and how certain work (ultimately recognized as markers of an individuals' success and warranting professional advancement) is privileged and allows exploration of the current P\&T system, our data, and its implications with a more critical perspective. This critical perspective includes around the merits and concerns with the current P\&T system (including around faculty I\&E), what our research and data can inform and challenge, and our assertions for deliberations that must be had around notions of privilege and power when considering any changes to P\&T structures and processes.

Value creation theory from Miller [79] is an economic theory used to explore organizational behavior and economic activity. Value creation theory is derived from social action theory and social value theories to explain and predict how and to what degree humans ascribe worth to things, including persons, ideas, processes, and physical objects. Social action theory, based on the sociologist Weber [80], suggests that individuals adapt their activities according to social contexts and the worth ascribed in these. Social action theory explains and predicts the behaviors and (potential) consequences of human behavior, including behaviors of groups and larger society as human behavior is often not the isolated behaviors of individuals, but replications and norms across groups and larger segments of society. Social value theory has historically concerned the economic value of tangible items (i.e., products, goods, and services) as well as intangibles such as skills, interactivity and networking, connectivity, information and knowledge, and effectively managing relational capital. Miller argued for a reconceptualization of social value theory from primarily an economic theory to one that also attends to human interactions and organizational activity. Value creation considers the integration of social and economic resources as creating mutually beneficial and satisfactory outcomes for individuals and organizations. Value creation theory illuminates the potential social and economic value that institutions and departments may place (explicitly and inadvertently) on faculty I\&E work and how that leads (or not) to P\&T considerations. Although value creation theory is typically applied to settings related to management and economic behavior, we use it to unpack our findings around what institutions value or not related to I\&E in P\&T considerations, largely as performance measures.

These performance measures are largely thought to equate to a faculty member's level of successes (or failures). Human capital theory [81] is useful here as well, in illuminating why a faculty member's performance measures are perceived as valuable by the various stakeholders involved in P\&T processes, within context. Human capital theory postulates that the degree of an individual's success being recognized by others is ultimately dependent upon an individual's skills and attributes being perceived as vital to the success of organizations of people. Per our interests, organizations may include departments, disciplines, and institutions. The premises of human capital theory, it can be argued, are the 
main rationale for education and training of individuals, that "increases productivity and efficiency of workers by increasing the level of cognitive stock" [82]. Becker [81] broadened the definition of human capital to include more than just knowledge or skills but also "competencies," and "attitudes" such as "reliability, honesty, self-reliance, and individual responsibility" (p. 6). We use human capital theory to explore how value and valuing interacts with assessment of human work, specifically why faculty attributes and actions may be seen as deserving of consideration in P\&T cases, including potentially as vital to the success of an organization, toward its goals or others valued by society. Human capital theory illuminates the "capital" individuals hold (what is valued by an organization), how individuals build this, and who has power to evolve what capital is valued. Human capital theory can also explain and predict organizations' investment in faculty I\&E activities (or not). Figure 1 shows our perception of the relationship and interactions between these theories, concerning our research interests.

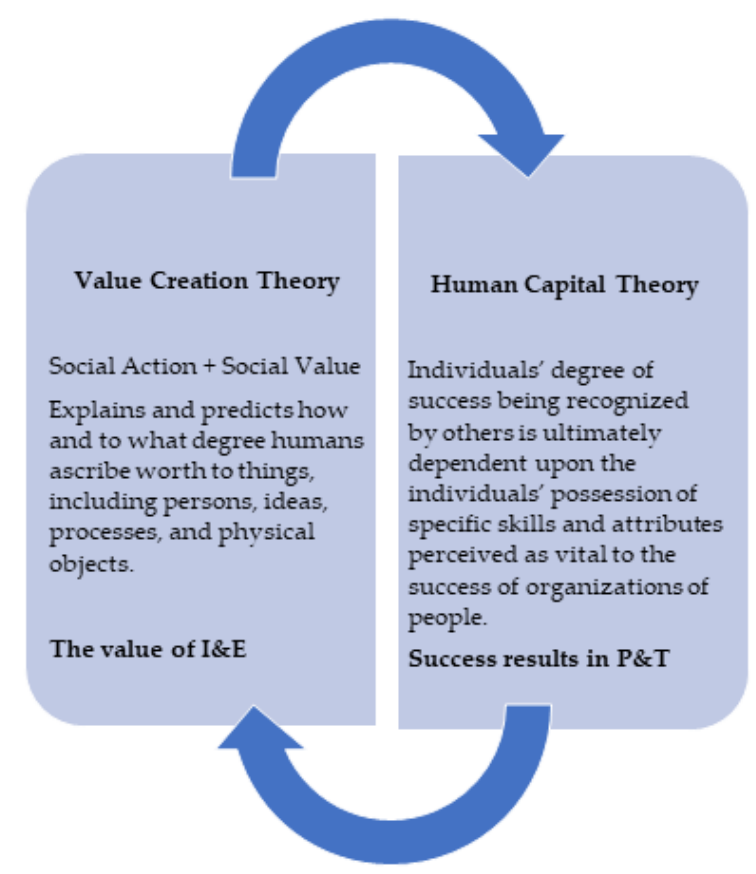

Figure 1. The relationship between value creation theory [79] and human capital theory [81] considering research interests.

\subsection{Methods}

We implemented a survey to gain an understanding of the current terrain of factors relevant to the evaluation of tenure-line faculty members' I\&E in P\&T considerations, including training for students, across US institutions of higher education. Our 27-item survey included adapted items from previously validated research surveys (see [35]). Alongside items of our creation, our survey asked about faculty I\&E in promotion and tenure policies and practices, how their institutions and organizations (e.g., department, discipline) are currently influencing this, the extent to which diverse institutions of higher education personnel value faculty I\&E, how able they feel in evaluating it, relevant faculty and student training, and interests in collaborative efforts in integrating I\&E in P\&T. Survey drafts were reviewed by administrators and faculty representatives (across targeted institution types) for appropriate relevance and validity; suggested changes were discussed by the researcher group (paper authors representing diverse disciplinary backgrounds and expertise) and adjustments were made accordingly.

We emailed the survey to 845 representatives from 377 institutions across eight Carnegie classification designations [83], Doctoral Universities with Very High Research Activity (R1), Doctoral Universities with High Research Activity (R2), Master's Colleges 
and Universities-Large (ML), Baccalaureate Colleges (BC), Tribal Colleges (TC), Medical Schools and Centers (MS), Historically Black Colleges \& Universities (HBCU), and Hispanic Serving Institutions (HSI). Of these, several were I-Corps affiliated institutions (I-Corp). The institutions were selected with several other key factors in mind. We targeted two institutions from each state to ensure geographic diversity, and overlaid our final loss of potential institutions by type and geography against a list of top ranked minority serving intuitions to also target representation from this group (Historically Black Colleges and Universities, Hispanic serving institutions, and Native American serving institutions). We chose the parameters of our sample to inform directions for revised structures and processes across a diversity of institutions via future work with a manageable number of universities that may wish to work collaboratively on revised structures and processes around I\&E in P\&T considerations. (This collaborative work, via the newly created Promotion and Tenure, Innovation and Entrepreneurship Coalition, is detailed in the Conclusion section of this paper.)

We sent the surveys to those assumed to possess relevant knowledge: upper administrators (provosts, associate and vice provosts, $n=377$ ), mid-level administrators (deans or heads of colleges, $n=242)$, and NSF I-Corps university contacts $(n=226)$. We sent upward of two email reminders, roughly one week apart. We asked these initial contacts to forward the email with the survey link to others at their institution that they thought may possess relevant knowledge and suggested certain individuals for consideration, such as mid-level administrators (deans or heads of colleges), department chairs, and other relevant faculty (e.g., faculty senate presidents).

Of the 377 institutions targeted, representatives from 99 unique institutions responded, via 123 representative individuals, for an institutional response rate of $26 \%$. (See Tables 1 and 2 for institutional and representative response). Final respondents included provosts ( $n=18)$ associate provosts and associate vice presidents of research $(n=63)$, I-Corps affiliated contacts $(n=20)$, and faculty leads and program directors (college-level and below) $(n=14)$.

Table 1. Number of survey respondents from different types of institutions, and total number of institutions with any survey respondents. There were 13 institutions that submitted multiple survey responses from different personnel. The number of duplicate responses ranged from 2-8, with 2 being the median number of duplicates (R1: $n=19$, R2: $n=2$, ML: $n=11, \mathrm{BC}: n=5$; where $n=$ number of duplicates).

\begin{tabular}{ccc}
\hline Types of Institutions & $\begin{array}{c}\text { Total Representatives per } \\
\text { Institution Type }\end{array}$ & $\begin{array}{c}\text { Total Institution Type } \\
\text { Responded/Contacted }\end{array}$ \\
\hline Doctoral universities/very high research activity (R1) & 57 & $46 / 121$ \\
Doctoral universities /high research activity (R2) & 14 & $13 / 36$ \\
Master's colleges and universities-large (M1) & 32 & $23 / 119$ \\
Baccalaureate colleges (BC) & 19 & $16 / 87$ \\
Tribal colleges (TC) & 0 & $0 / 11$ \\
Medical schools and centers (MS) & 1 & $1 / 3$ \\
Totals & 123 & $99 / 377$ \\
\hline
\end{tabular}

Table 2. Number and type of institution recognized as Historically Black Colleges \& Universities (HBCU), Hispanic Serving institutions (HSI), and/or I-Corps affiliated institutions that were contacted and responded $(n=18$ duplicate responses from I-CORP affiliates and $n=2$ from HSIs.)

\begin{tabular}{cccc}
\hline Institution Type & $\begin{array}{c}\text { HBCU } \\
\text { Responses/Contacted }\end{array}$ & $\begin{array}{c}\text { HSI } \\
\text { Responses/Contacted }\end{array}$ & $\begin{array}{c}\text { I-Corps-Affiliated } \\
\text { Responses/Contacted }\end{array}$ \\
\hline Doc univ very high (R1) & $0 / 0$ & $4 / 8$ & $41 / 69$ \\
Doc univ high (R2) & $2 / 8$ & $3 / 7$ & $10 / 22$ \\
Master's-large (ML) & $2 / 9$ & $1 / 25$ & $0 / 2$ \\
Baccalaureate (BC) & $2 / 6$ & $0 / 1$ & $0 / 0$ \\
Med. schools and centers (MS) & $0 / 0$ & $0 / 2$ & $0 / 1$ \\
Totals & $6 / 23$ & $8 / 43$ & $51 / 94$ \\
\hline
\end{tabular}


Data were downloaded from Qualtrics and analyzed using SPSS Statistics. Descriptive data analysis was performed across type of respondents as well as type of institutions. Chi-square tests of independence were performed to examine relationships between respondents' claims of evaluation of faculty I\&E in P\&T at their institutions across five discipline areas: the applied and professional sciences, the formal sciences, the natural sciences, the social sciences, and the humanities.

\subsection{Limitations}

We note various limitations of our exploratory research. Our sample was selected to inform direction for a future coalition that could then work collaboratively on revised structures and processes around I\&E in P\&T considerations. Due to nonprobability, convenience sampling methods and our limited sample of institutions, we do not believe our respondent sample to be adequately representative of a larger population. While we achieved a respectable institutional response rate, certain types of institutions were exceptionally limited in total number of respondents, which further limited total responses on many of the survey items. As well, related personnel providing perspective from institutions was also limited, often only one individual from an institution presenting individualized, and arguably biased, experiences. For several universities, multiple respondents may have further biased results.

Our entire sample was also likely biased due to its use voluntary participation; individuals who choose to participate in a study may not fully represent the population from which the sample has been drawn [84], including the likelihood that individuals who feel strongly about an issue were the most likely to have responded to a survey [85]. Since we did not have access to a population representative enough of a greater diversity of institutions and their personnel, we could not adequately assess the degree to which our sample of convenience represents a larger population [86]. Thus, we relied on descriptive statistics to help understand data associated with this sample only, largely not utilizing inferential statistics to make generalizations. We did perform comparisons of I\&E considerations in P\&T cases across different groups of disciplines, around questions for which we think we had enough total number of responses, and per an assumption that disciplines are a relevant factor that hold more consistently across institutions. Still, overall, our exploratory research provides limited insights, and we encourage future research that can uncover pertinent realities at a larger array of institutions and for a larger array of their faculty (across position types). We specifically recommend future studies built on sampling methods that can allow generalizability via inferential statistical analysis.

\section{Results}

\subsection{To What Extent Is Faculty Members' IEE Activity Valued?}

Across position types, personnel at institutions of higher education think it is important to evaluate faculty members' I\&E when considering P\&T cases at their institutions; 79\% $(89 / 112)$ of individuals agreed or strongly agreed with this statement and I-Corp-affiliated personnel always did (18/18) (Figure 2). Across institution types, when asked if others at their institution recognized this importance, the across-sample trend leaned slightly more positive, with $42 \%$ (49/116) of responses agreeing or strongly agreeing, versus 32\% disagreeing (37/116). Those from R1s, BCs, and I-Corps reported more conflicted realities, with roughly half agreeing and disagreeing with this statement (Figure 3). Across institution types, there was general agreement that rewarding I\&E in P\&T cases is important for retaining faculty $(57 \%, 66 / 116$ indicating agree or strongly agree) (Figure 4 ). 


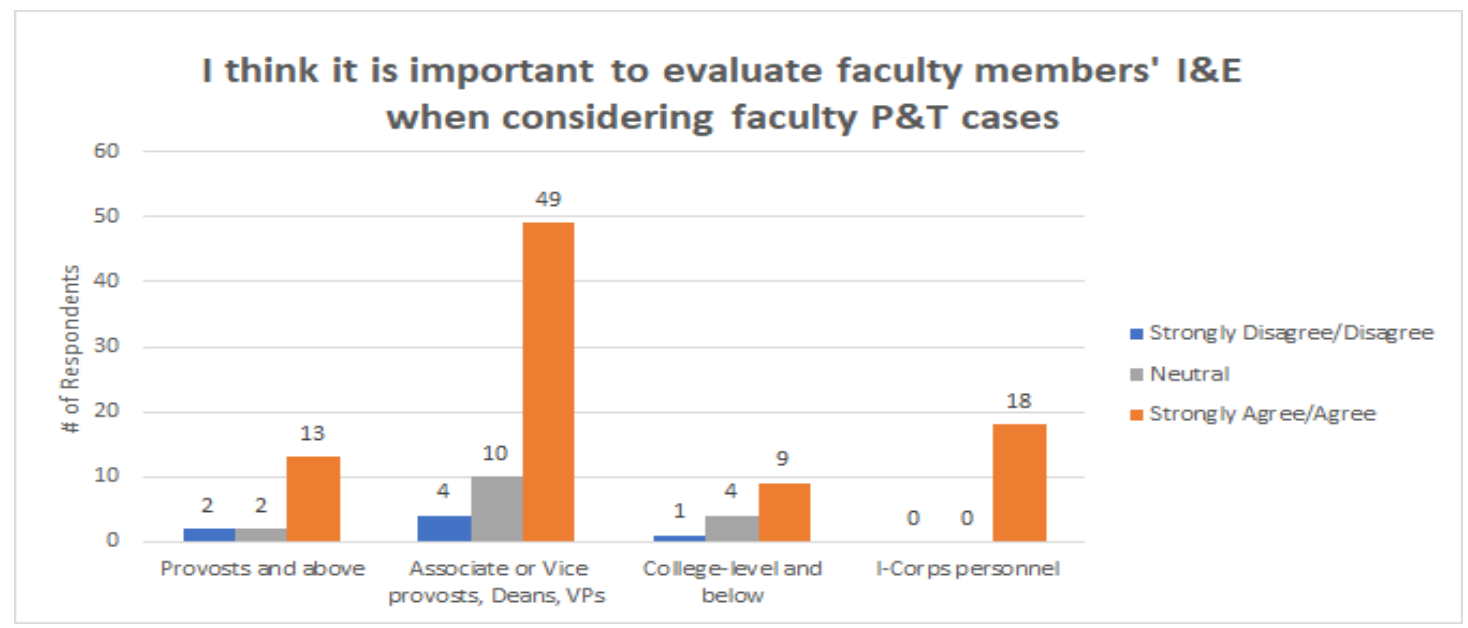

Figure 2. Comparison of IHE personnel's perceptions of the importance of evaluating faculty members' I\&E when considering faculty $\mathrm{P} \& \mathrm{~T}$ cases at their institutions.

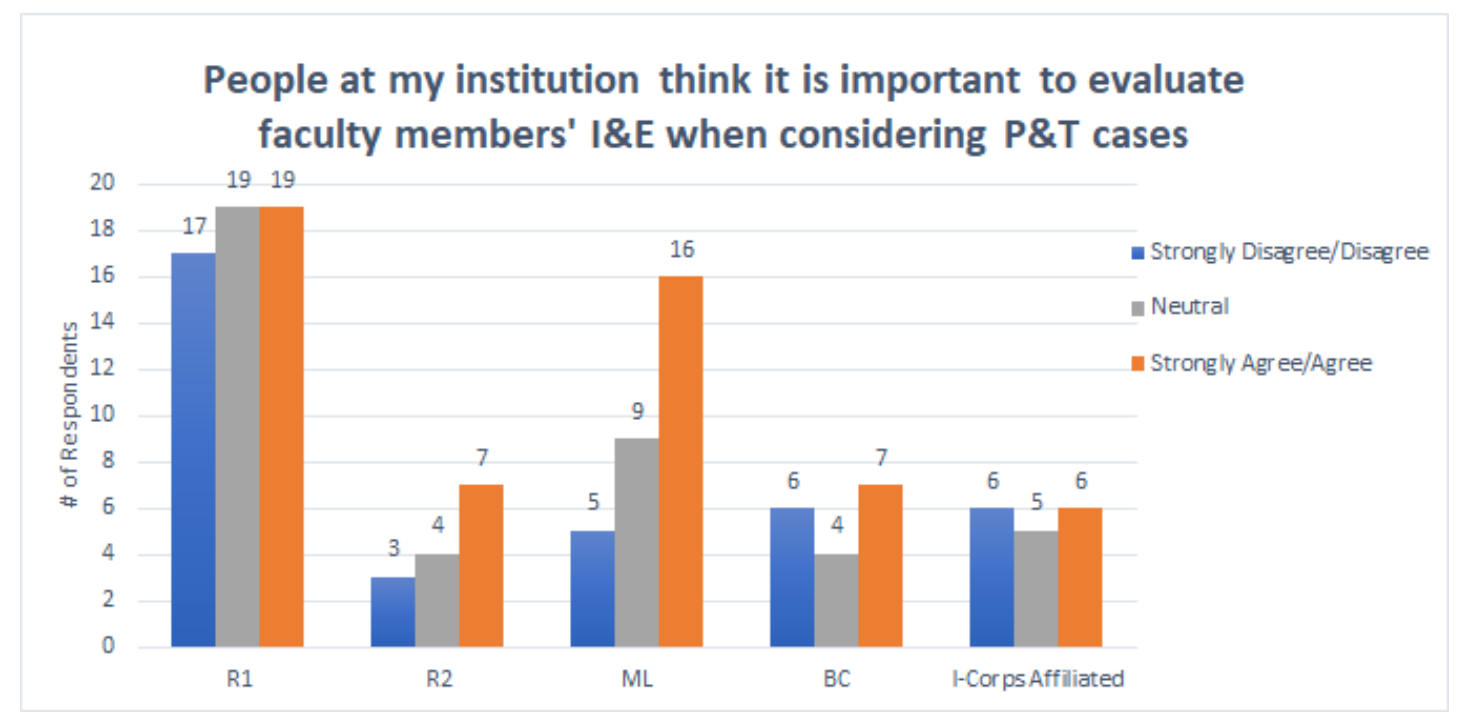

Figure 3. Comparison of respondents' perceptions of how other people at their institution regard the importance of evaluating faculty members' I\&E when considering faculty P\&T cases at their institutions.

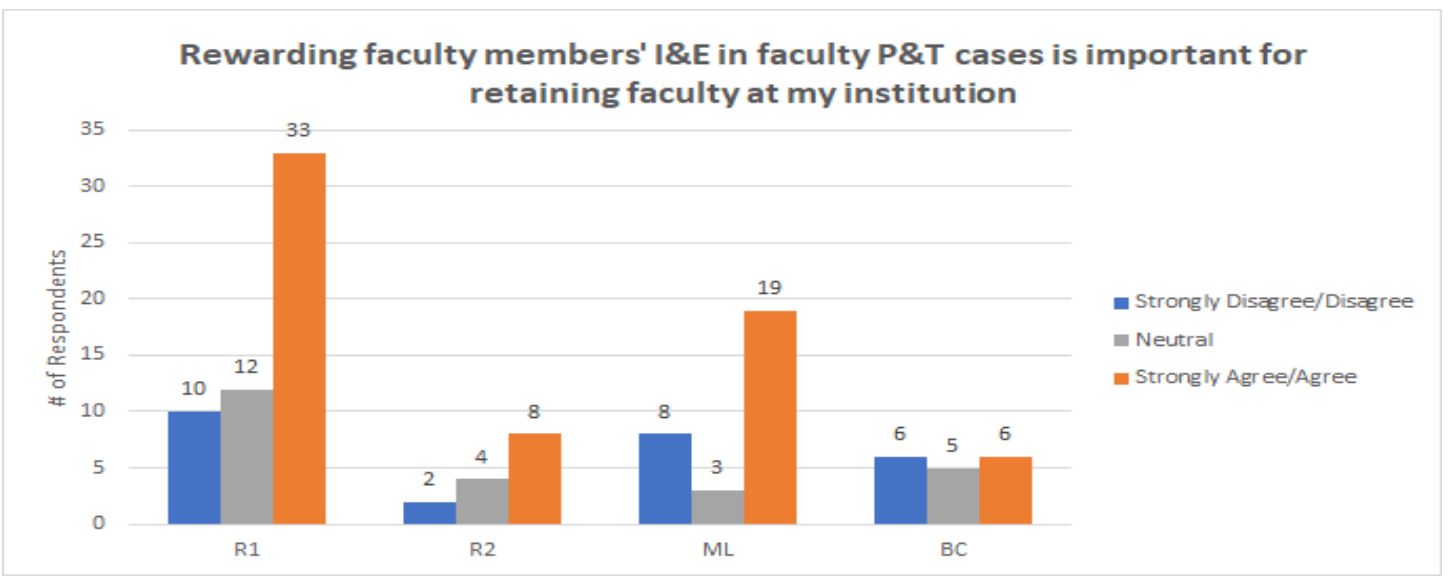

Figure 4. Comparison of institution type responses about rewarding faculty members' I\&E in P\&T as important for retaining faculty at the institution. 
Across personnel and institution types, about half $(48 \%, 56 / 117)$ claimed some valuing of faculty efforts to develop students for careers that include I\&E. Those at R1s and I-Corp affiliated institutions indicated almost equal disagreement as agreement with this statement (Figures 5 and 6).

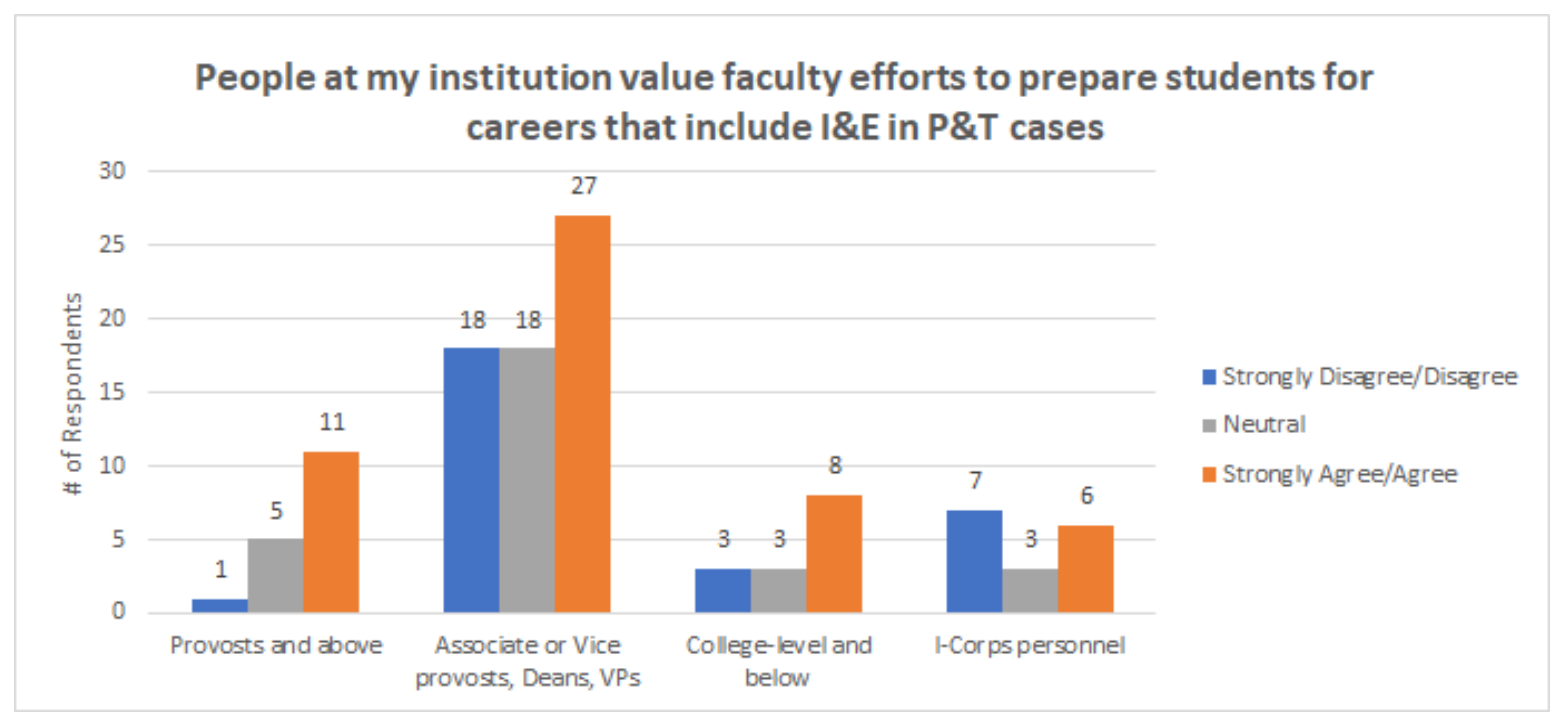

Figure 5. Comparison of respondents' perceptions of how other people at their institution value in P\&T cases faculty efforts to prepare students for careers that include I\&E.

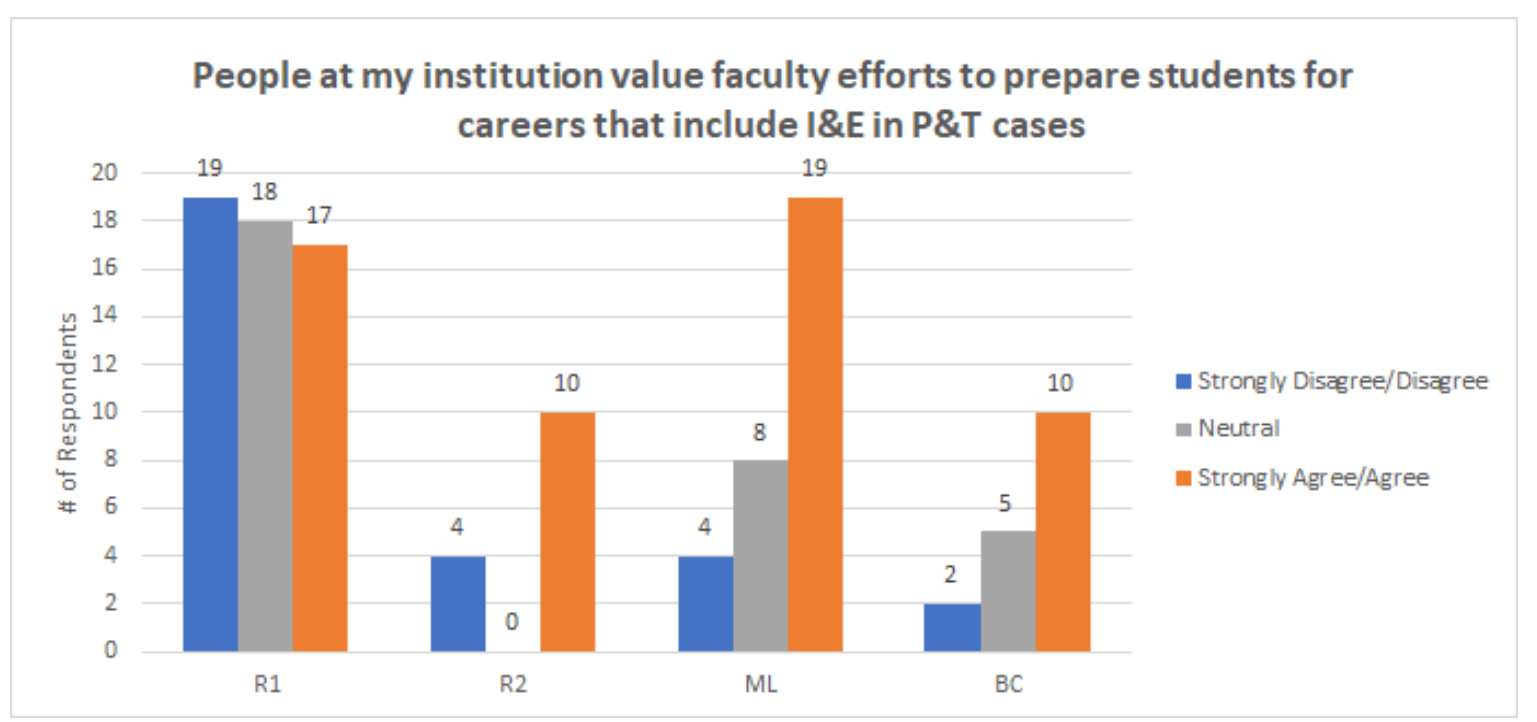

Figure 6. Comparison of institution type responses related to how people at their institution value in P\&T cases faculty efforts to prepare students for careers that include I\&E.

3.2. To What Extent Do Relevant Personnel Feel Able in Evaluating Faculty Members' IEE Activity in Promotion and Tenure Cases?

Across position types, institutions of higher education personnel generally felt themselves competent in evaluating faculty members' I\&E when considering P\&T cases at their institutions; $73 \%$ (80/110) of respondents agreed or strongly agreed with this statement. Yet respondents were less certain that others at their institutions possessed this competency, with similar amounts of agreement and disagreement and feeling neutral about this statement across the sample (Figure 7). 


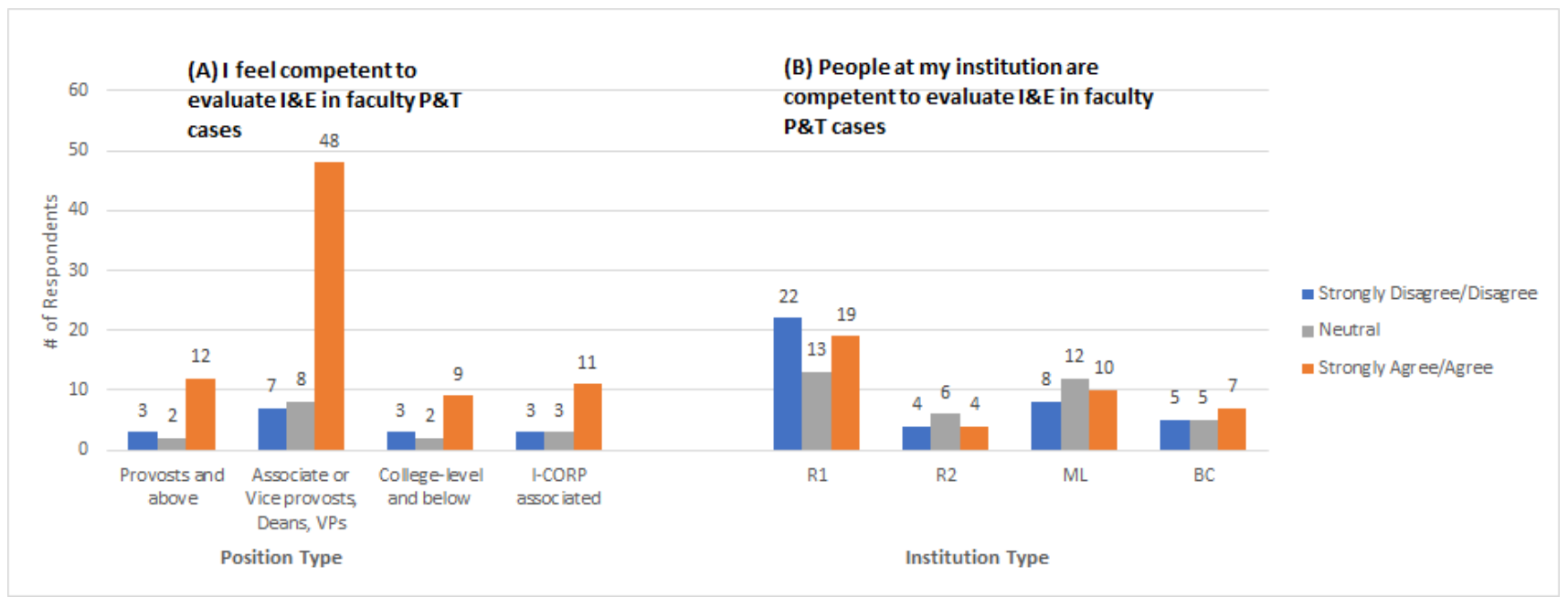

Figure 7. Comparison of felt competencies by position types in evaluating faculty members' I\&E when considering P\&T cases (A) and the same sample by institution types, the degree to which they felt others at their institutions possessed this competency (B).

3.3. To What Degree Is Faculty Members' IEE Activity a Consideration in the Evaluation of Their Work for Awarding of Promotion and Tenure across Various Institutional Organizations (e.g., Departments and Disciplines), as Reflected in Policy?

Across institution types, 69\% (69/100) of respondents indicated there were no policy statements that existed to guide evaluation of faculty I\&E counting in P\&T, although R2s reported slightly more likelihood (7/13) of these policies than not (6/13) (Figure 8). For R1s and I-Corp affiliated institutions, these policies were noted present at about one-third of institutions, at about one-fourth of MLs, and at about one-tenth of BCs. When policies did exist, they were most likely found at the department level at R1s and MLs, the institutional level at baccalaureate colleges (BCs), and either the school or college or department level at R2s (Figure 9). Few policies were being developed across institutions of higher education; $71 \%(81 / 114)$ of respondents indicated they knew of none in the works (Figure 10). The few being developed across institution type were mostly likely being developed at the department level.

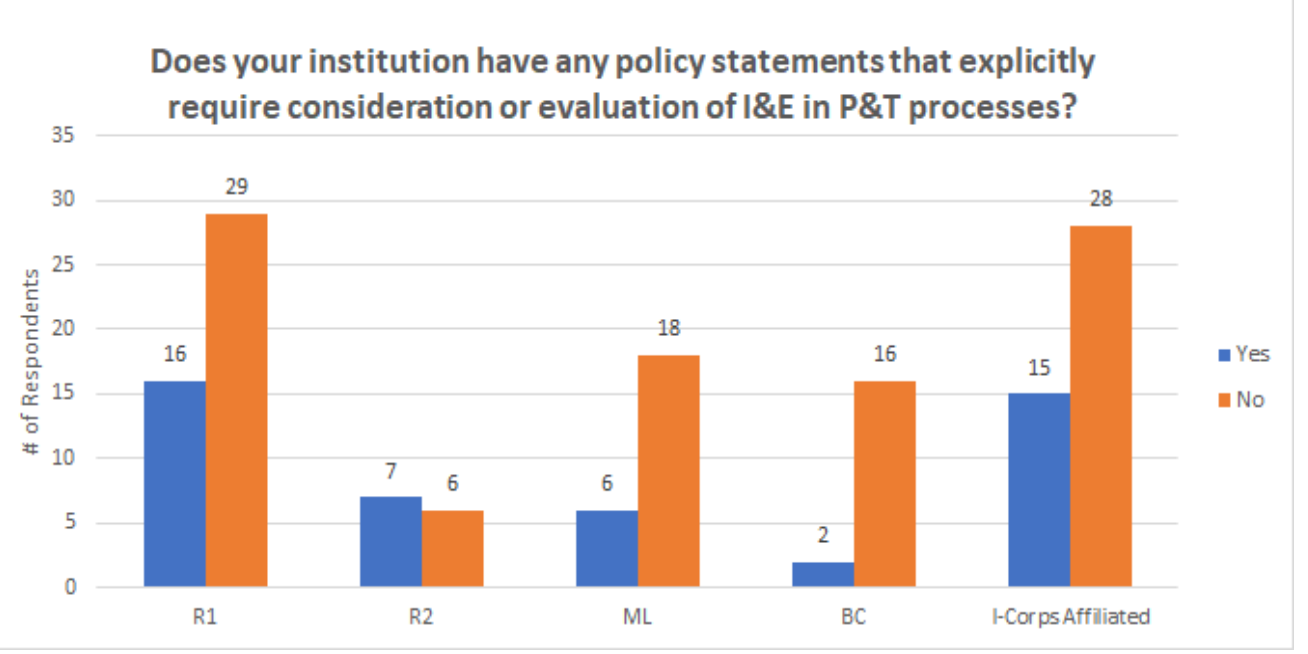

Figure 8. Comparison of institution type responses, including I-Corps affiliated institutions, on the existence of policy statements that require consideration or evaluation of I\&E in P\&T processes at their institutions. 


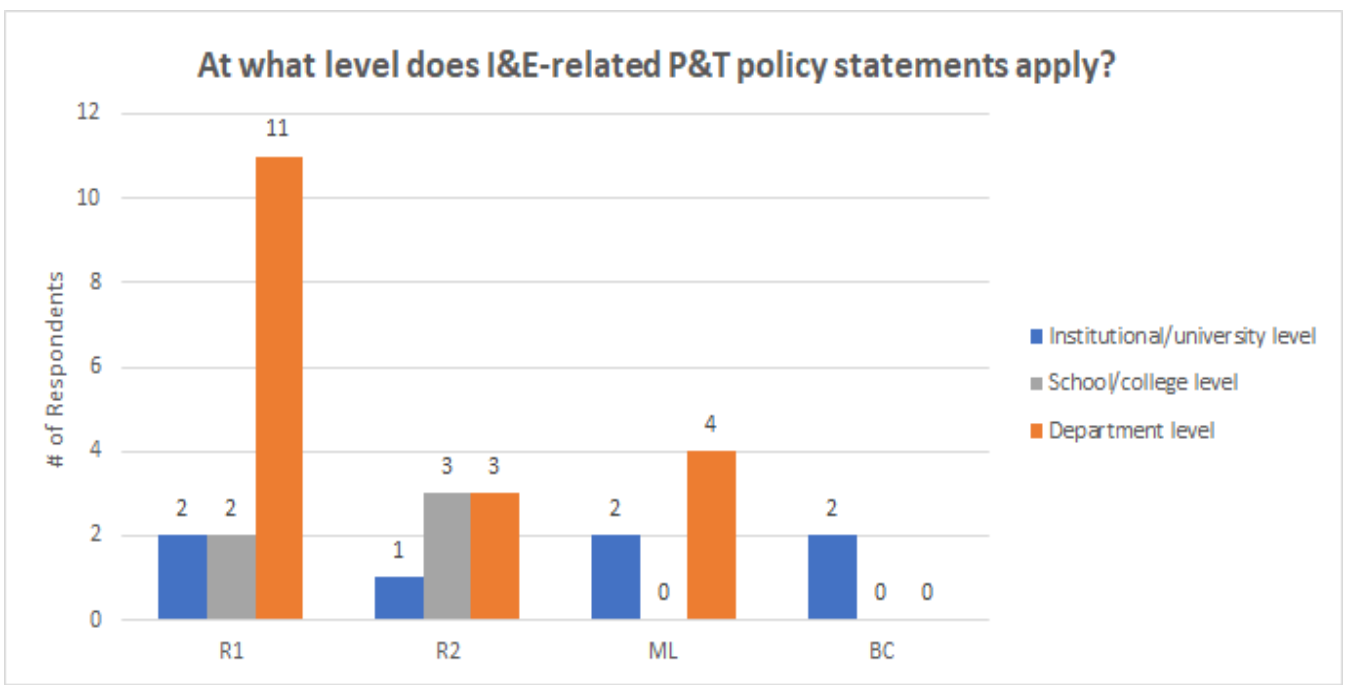

Figure 9. Comparison of institution type responses of the level where I\&E related P\&T policy statements apply at their institutions.

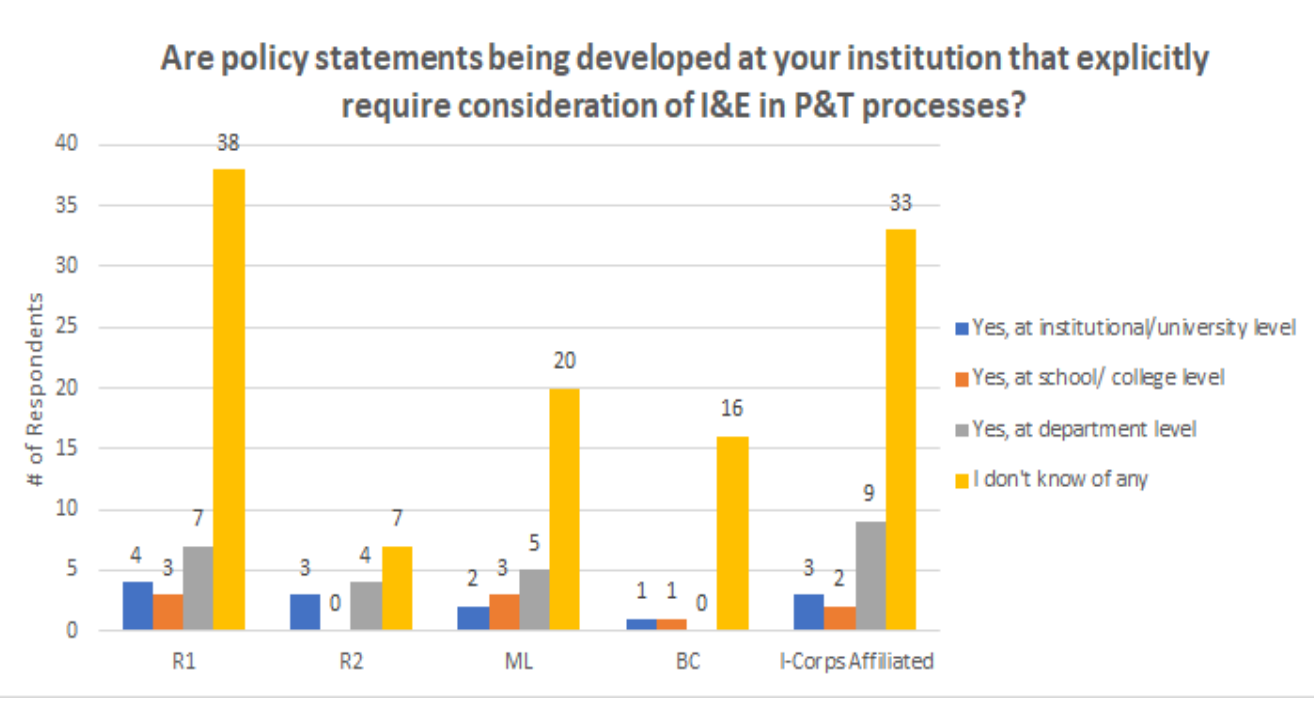

Figure 10. Comparison of institution type responses, including I-Corps affiliated institutions, whether policy statements are being developed that require consideration of I\&E in P\&T processes at their institutions.

3.4. To What Degree Is Faculty Members' IEE Activity a Consideration in the Evaluation of Their Work for Awarding of Promotion and Tenure across Various Institutional Organizations (e.g., Departments and Disciplines), as Reflected in Practice?

An almost equal number of respondents claimed some evaluation of faculty I\&E in P\&T considerations to be happening at their institutions versus those that claimed not (Figure 11). When it was noted as happening, across university type, chi-square tests of independence showed that respondents claimed it to be significantly more likely in cases of faculty in the applied and professional sciences (67\%), the natural (65\%), and formal sciences $(62 \%)$, in comparison to those in the social sciences $(29 \%)$ and humanities $(17 \%)$ (Table 3 and Figure 12). No significant differences existed between responses concerning the professional, natural, and formal sciences, or between the social sciences and humanities. 


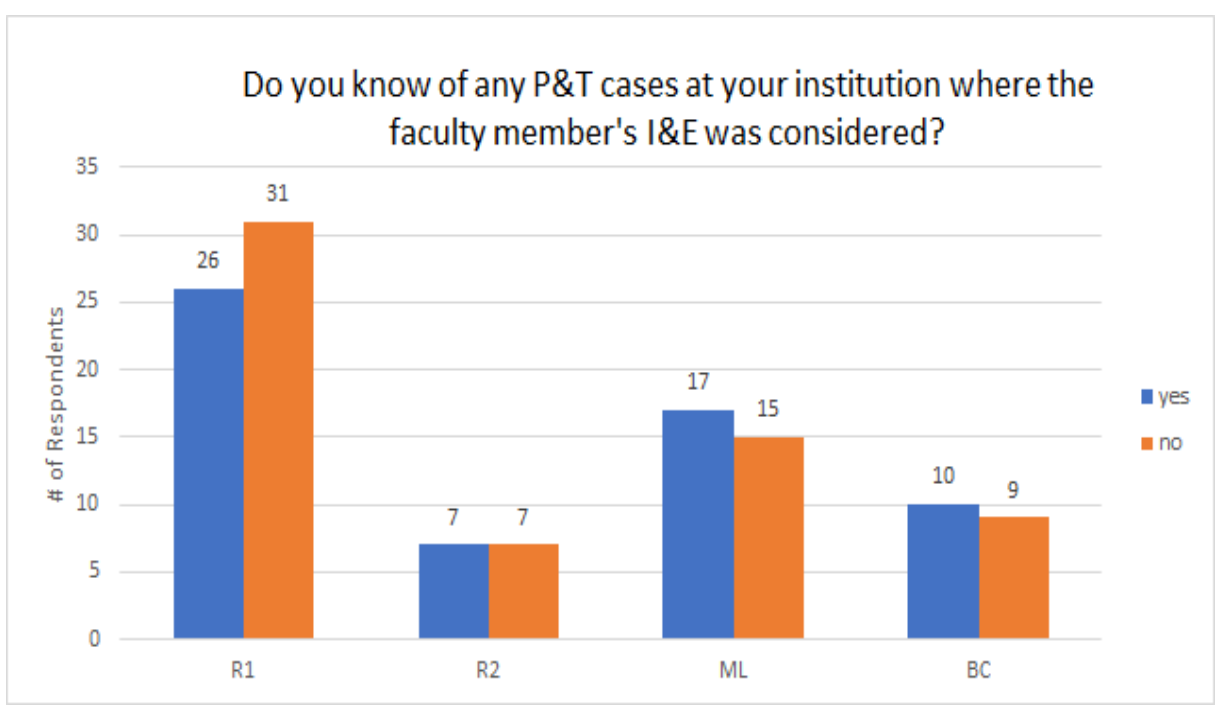

Figure 11. Comparison of institution type responses of P\&T cases where faculty members' I\&E were considered at their institutions.

Table 3. Chi-square statistic/ $p$-value from chi-square tests of independence between respondents claims of evaluation of faculty I\&E in P\&T at their institutions across five discipline areas; degrees of freedom $=1$; significance at $p<0.01$. Bolded text equates to a significant difference.

\begin{tabular}{cccccc}
\hline Discipline Area & Applied/Pro. Science & Formal Sciences & Natural Sciences & Social Sciences & Humanities \\
\hline Applied/ & & 0.3029 & 0.0411 & 15.1784 & 26.4176 \\
professional sciences & & 0.582052 & 0.839323 & $<\mathbf{0 0 0 0 9 8}$ & $<\mathbf{0 . 0 0 0 0 1}$ \\
Formal sciences & 0.3029 & & 0.1223 & 11.2191 & 21.2993 \\
& 0.582052 & & 0.726578 & $<\mathbf{0 0 0 8 1}$ & $<\mathbf{0 . 0 0 0 0 1}$ \\
Natural sciences & 0.0411 & 0.1223 & & 13.7529 & 24.625 \\
& 0.839323 & 0.726578 & & $<\mathbf{0 0 0 2 0 9}$ & 1.95 \\
Social sciences & 15.1784 & 11.2191 & 13.7529 & 0.162587 \\
Humanities & $<\mathbf{0 . 0 0 0 0 9 8}$ & $<\mathbf{0 . 0 0 0 8 1}$ & $<\mathbf{0 . 0 0 0 2 0 9}$ & 1.95 & 0.162587 \\
\hline
\end{tabular}

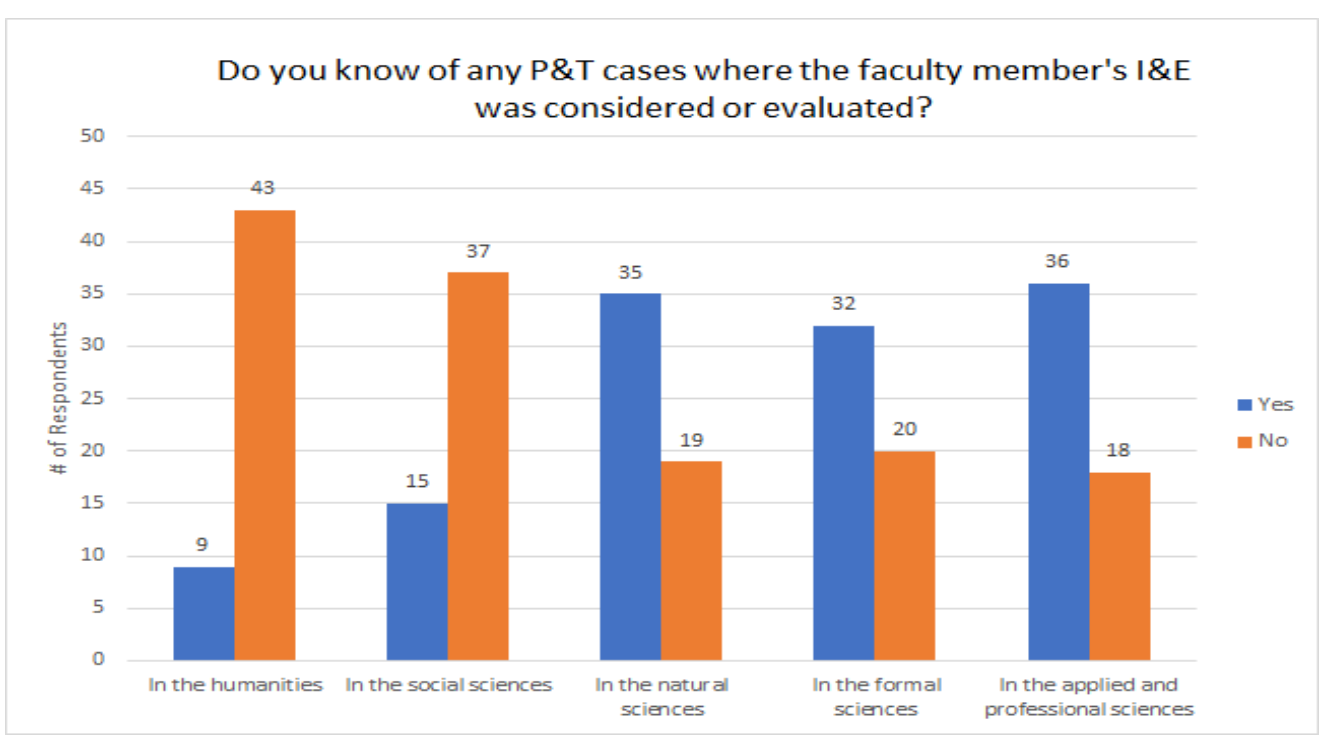

Figure 12. Comparison of I\&E considerations in P\&T processes across disciplines at respondents' institutions. 
Of known cases, 55\% (43/78) of respondents claimed faculty I\&E was perceived as a somewhat or very important factor at the institutional review level, compared to $61 \%$ $(48 / 79)$ at the school/college and $75 \%(66 / 88)$ at the department level (Figure 13). When I\&E was considered in P\&T cases, it was deemed optional (not a required faculty activity) by $78 \%$ of respondents $(62 / 79)$, and deemed flexible by $63 \%$ (50/80) (to acknowledge high-quality faculty work in multiple forms) (Figure 14).

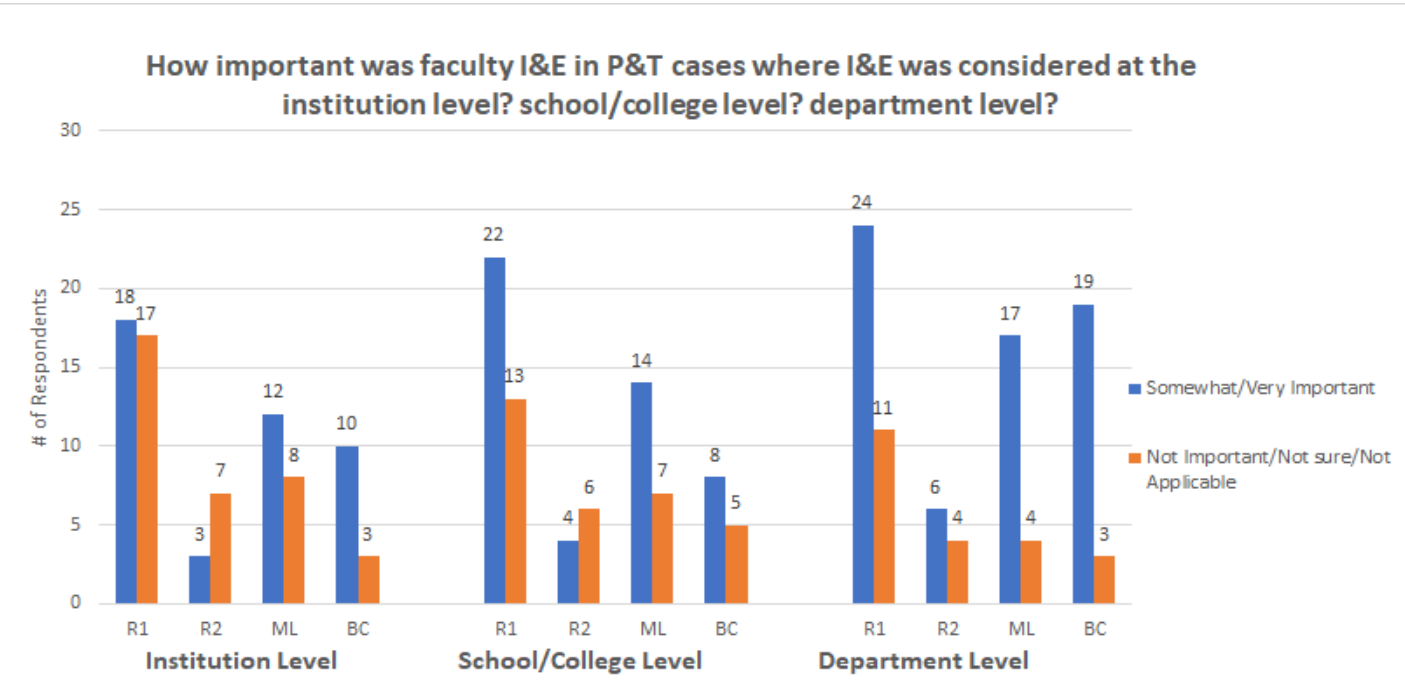

Figure 13. Comparison of institution type responses of level of importance of faculty I\&E in P\&T cases at institution, school or college, and department levels at their institutions.

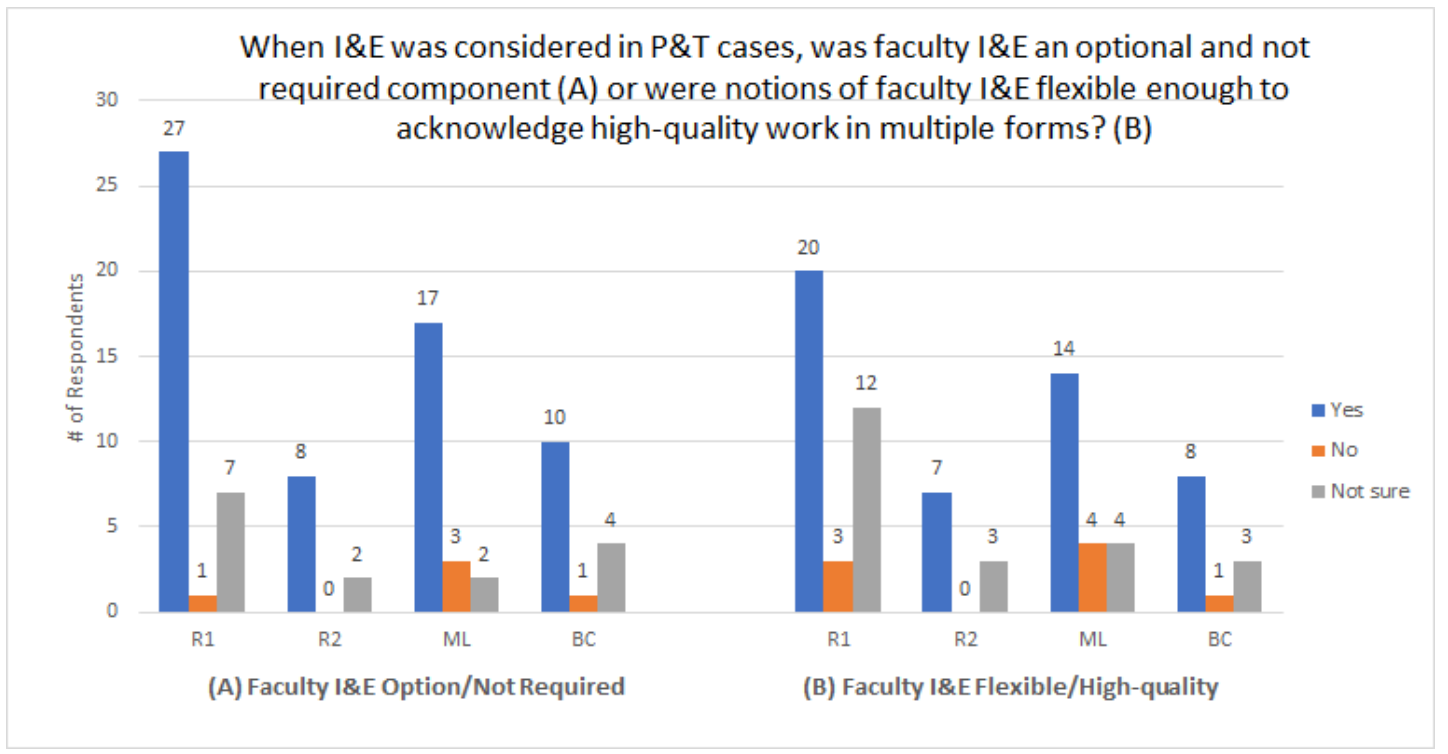

Figure 14. Comparison of institution type responses of the optional and flexible nature of faculty I\&E when it was considered in P\&T cases at their institutions.

3.5. What IEE-Related Training, for Faculty (Including for Underrepresented Groups), Postdoctoral Researchers, and Students, Is Offered at Institutions?

Across institution types, scant training regarding faculty I\&E was noted. Almost all respondents indicated no training for evaluation of faculty I\&E for administrators $(92 \%$ $(104 / 113)$ or faculty $(90 \%, 101 / 112)$ (Figure 15). 


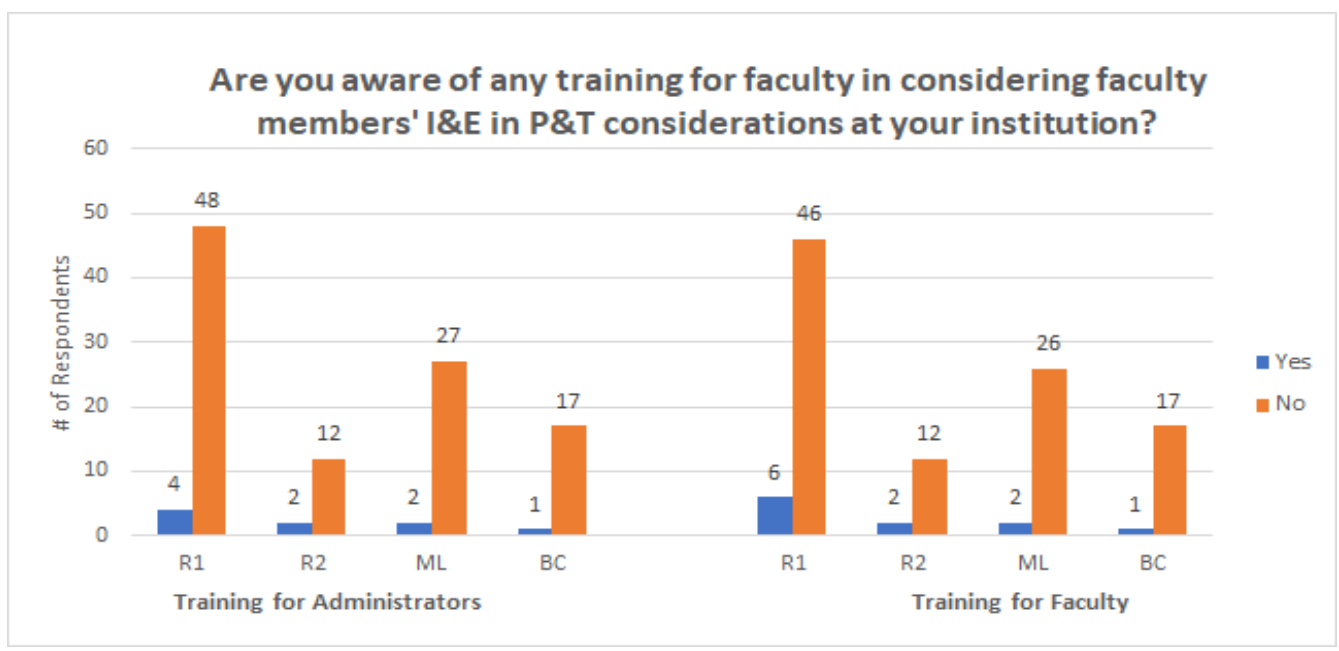

Figure 15. Comparison of institution type responses of the awareness of any training for administrators or faculty in considering faculty members' I\&E in P\&T considerations at their institutions.

Sixty-four percent $(64 \%, 72 / 113)$ of total respondents noted training for faculty engagement in I\&E across types of institutions, mostly at R1s $(85 \%, 44 / 52)$ and R2s $(86 \%, 12 / 14)$; of this, little training was noted as targeting underrepresented groups of faculty, with only $27 \%(31 / 113)$ of respondents indicating this was available, most likely at R1s $(37 \%, 19 / 51)$ and R2s $(43 \%, 6 / 14)$. Training targeting underrepresented faculty groups was atypical across the sample (Figure 16). Training for postdoctoral engagement in I\&E seemed likely at those institutions most likely to host them, mostly at R1s and R2s (with 36/47 and 10/12 indicating this training was available at those institution types, respectively). Only $20 \%$ $(23 / 113)$ of respondents indicated training for undergraduate students in engagement in I\&E at their institution, more likely at MLs and BCs. Across institutions, little training for graduate students was claimed, with only $11 \%(12 / 113)$ indicating institutional availability, and R1s and R2s (where graduate students are found in higher numbers) largely void of this affordance (with only 6/59 R1 and R2 respondents claiming it) (Figure 17).

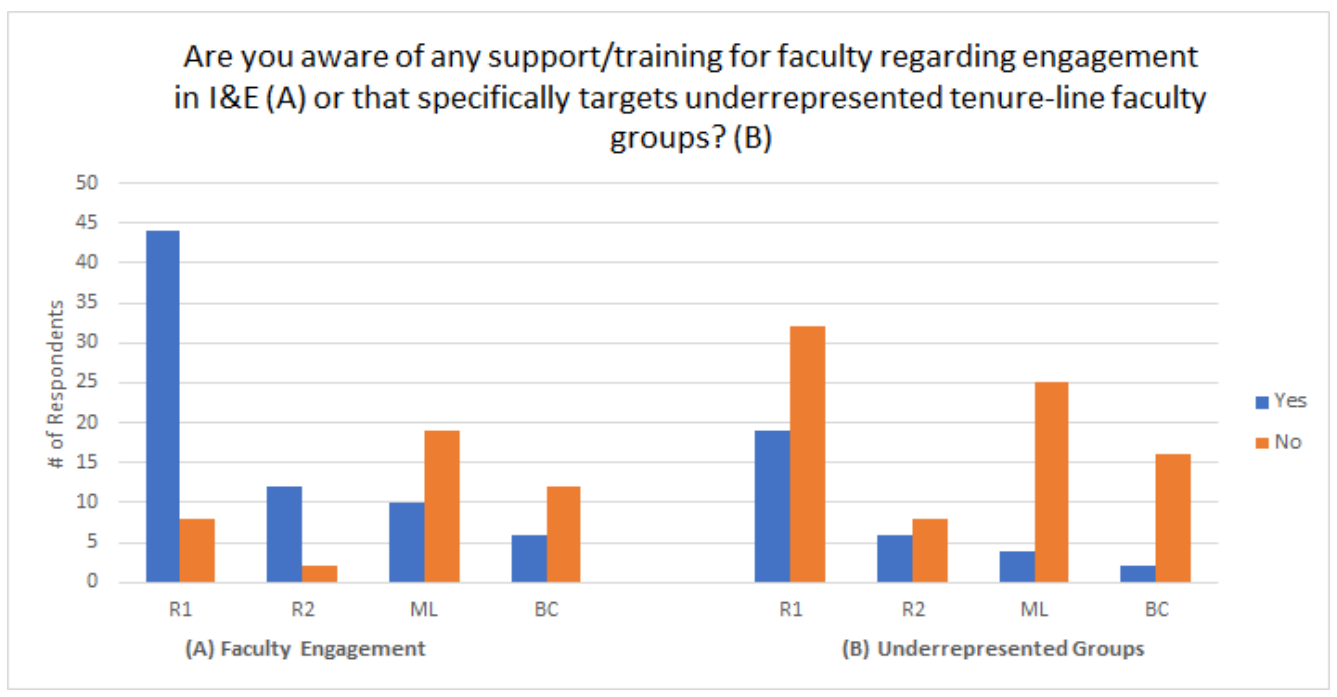

Figure 16. Comparison of institution type responses of awareness of support or training at their institution that specifically targets faculty engaging in I\&E or underrepresented tenure-line faculty groups (e.g., women faculty, faculty of color) engaging in I\&E. 


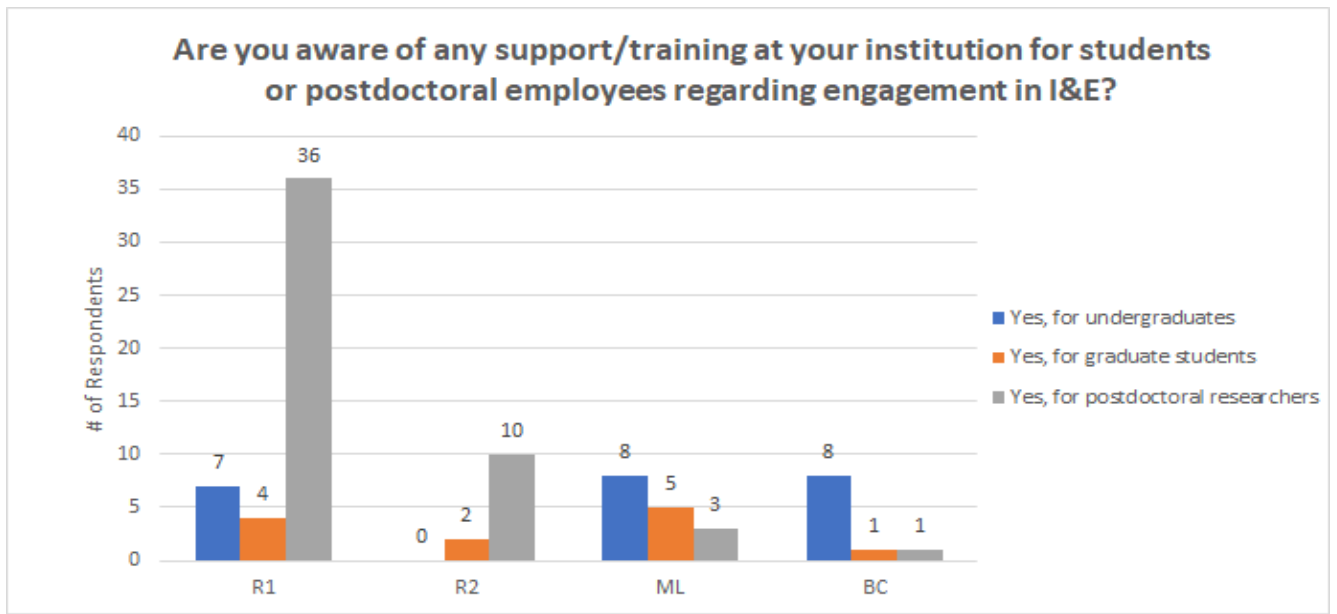

Figure 17. Comparison of institution type responses of known awareness of support or training at their institution for students or postdoctoral employees regarding engagement in I\&E.

\section{Discussion}

Via survey responses, we heard from 123 personnel from 99 diverse institutions of higher education in the US about their perceptions of current consideration of faculty I\&E in P\&T structures and processes. Overall, while it seemed there was plenty of interest to consider I\&E in P\&T cases, there was corresponding need to work to change norms at and across institutions to allow this to any appreciable degree. In this, we read value ascribed to faculty I\&E, potentially for economic reasons, and also likely for other social reasons. Decades, centuries perhaps, of the positive societal impacts of faculty I\&E is likely well-known to many leaders and faculty across institutions. About half of our survey respondents, across personnel and institution types, claimed valuing of faculty efforts, specifically, to develop students for careers that include I\&E. We assume that academics often see one role of faculty and their organizations to be the preparation of students for their futures, which involve increasingly complex socio-scientific needs. Respondents from R1s and I-Corp affiliated institutions indicated less valuing of faculty efforts around developing students in the I\&E realm than we anticipated. This was perplexing per survey data, pointing to their faculty as being most engaged in I\&E activity (compared to other types of institutions), and a plethora of recent research (that I-Corp institutions may know of and attempt to build from) showing the payoffs of I\&E= development for students in terms of knowledge, skills, and job prospects (see [17] for review).

Overall, personnel across institutions we surveyed seemed to receive little to no training in evaluating faculty members' I\&E when considering P\&T cases. As well, policies for their evaluation of faculty I\&E in considerations of P\&T were generally lacking, indicating another key affordance was largely not available to guide such work. When policies did exist, the level they were found at varied by institution type. This lack of training and policies may also serve as an indication of the low worth ascribed to the assessment of I\&E in P\&T, and faculty I\&E activity overall. Institutions of higher education are diverse in their internal handling of promotion and tenure evaluations and in the use of policies to these (and organizational practices writ large). Still, the creation and institutionalization of policies around I\&E in P\&T considerations should not be ignored, as key structural affordances that can help faculty understand and enact changes to P\&T-related practices can feel challenging to the cultural norms they are used to and likely value. Policies can both mandate and sustain new practices, to the point of becoming routine, and this is one type of affordance that can help to encourage legitimizing, and thus valuing, faculty P\&T. Institutions may need to synchronize policies at various levels (e.g., the department and institutional level) so that the multiple review committees involved can evaluate P\&T cases with the same I\&E-related criteria and perceptions of worth. 
Evaluation of faculty I\&E in P\&T considerations was reported by survey respondents to be happening, most often at the department level, although greatly dependent on the faculty field. Respondents claimed it significantly more likely to be happening in cases of faculty in the applied and professional sciences, natural, and formal sciences in comparison to those in the social sciences and humanities. Institutions hoping to promote and reward faculty I\&E may need to attend to the diversity in work across disciplines, the cultural norms around what work is privileged within and across disciplines at their institution, and potentially construct and promote definitions of I\&E that are inclusive. Per our later point, we see the need to conceptualize I\&E in a way that recognizes a diversity of faculty work, for instance with definitions and concepts aligned with Miller's [79] notion of value creation, which recognizes worth beyond physical and marketable objects, to include intangible skills toward enhancement for individuals and society. We envision the following definitions and concepts:

Innovation: the identification or creation of new resources (including methods, services, or technologies) with commercial or social good potential.

Innovation with commercial or social good potential: while faculty innovation is diverse in goals and impacts, faculty innovation has commercial (e.g., wearable technology, digital media) or greater social good potential (e.g., low cost water filtration methods, wildfire monitoring systems).

Entrepreneurship: recognizing and attempting to realize the commercial potential or business opportunities of innovation, faculty may or may not engage in entrepreneurship with respect to their innovations.

We need to expand the currently narrow perception of I\&E only being relevant to faculty in STEM fields, and deliberately embrace conceptions more inclusive of the diverse work of faculty across campuses-including in the humanities. More inclusive conceptions may bring more underrepresented groups to I\&E activity as well. Women in STEM tend to consider more the ethics of science, including concerns for the communities that will be impacted by their work, and worries about "selling" their scholarship or themselves through I\&E-related work $[73,87]$. We can learn from the multiple efforts to reform P\&T nationally that have been underway for some period of time, e.g., [88], including ones that have failed. To be successful in promoting I\&E, we must attend to any hinderances of past P\&T-related efforts, including that only certain segments of the faculty population can envision positive outcomes for their work if the goals of an effort are realized.

Respondents indicated that when evaluation of faculty I\&E in P\&T considerations did happen, it was be perceived as a somewhat important consideration by evaluators and an optional and flexible activity for faculty. These findings may point to varied realities, and perhaps some tensions, within and between institutions. Taken one way, they may point to a degree of flexibility in faculty I\&E, and its considerations in P\&T cases, that faculty and their organizations or institutions may feel important or necessary to ensure, perhaps similar to the flexibility seen around notions of faculty scholarships at many institutions. Within P\&T considerations, flexibility regarding the proportion of I\&E in the larger body of a faculty member's work, and flexibility concerning the characteristics of the I\&E work itself, may align with academic cultural norms that faculty promote, such as expertise and intellectual freedom. Taken another way, these findings may also point to a lack of structures or practices that have coalesced around shared conceptions of faculty I\&E, and how this work can be evaluated. These framings suggest considerations of issues of power and privilege in the academy, guiding faculty work and the assessment of it, as well as many decisions in academic organizations. What is valued by organizations of faculty, and how that came to be, must be considered at this juncture, as well as any related potential unintended consequences when considering revisions to practices and the structures.

No doubt, the idea of broadening what work is valued by faculty and their organizations in P\&T may concern others who may envision an unintended consequence of broadening the already large swath of work that faculty must attend to. We do not want to privilege faculty I\&E to the extent that it becomes required in addition to what is already 
required of faculty. Faculty working in the humanities or social sciences, regardless of attempts for inclusive definitions of I\&E (such as those offered above), may rightly be concerned for how their work is perceived. Could their work, they might wonder, that is less likely to be I\&E (or I\&E types most privileged), become less valued that that of their counterparts in other disciplines?

We must carefully consider any possible ramifications of changes regarding faculty work for groups already underrepresented and under-empowered in the faculty ranks. We need to ensure that we do not add any more incongruity between how faculty actually spend their time and what is considered in P\&T, especially for underrepresented groups in the faculty ranks. Durodoye et al. [7] remind those (re)considering P\&T structures to keep central in planning "biases deeply embedded in societal dynamics, and the ways these dynamics influence general and evaluative organizational processes" (p. 645). Training targeting underrepresented faculty groups was atypical across the sample. This seems an important affordance, especially realizing the benefits for these faculty per their participation in I\&E, as well as for balancing and being adequately and equitably awarded for such work.

Acknowledging the benefits to faculty who do engage in I\&E, and interactions with the private sector and industry specifically, to not provide targeted training to groups traditionally underrepresented in the faculty ranks may further place them at a professional disadvantage compared to their peers. For instance, the absence of STEM commercialization, patenting, and entrepreneurship in the promotion and tenure reward structure has been shown to disincentivize women and other underrepresented groups of STEM faculty from participating in entrepreneurship, in part per their overly full workloads [72]. A recent study points to the presence of a "star" faculty member, and the degree of interdisciplinarity of the team as predictors of success in commercialization efforts [89]. Specifically, patent collaborations are already less likely to involve interdisciplinary teams that include women, and for "star" faculty, experienced in commercialization and predictive of success efforts to be women [90]. Such findings may be the results of both lesser access to supports and networks and, thus, aversion to taking risks in their careers [91]. We need to take great care to not exacerbate these realities for faculty.

We must counteract biases that limit scientific progress [92]. Members of Congress, business leaders, social scientists, and university leaders continue to express the pressing need for better engagement of groups currently underrepresented in the innovation processes toward solutions to global problems and to enhance American competitiveness and GDP. Overall, we need to be sensitive to what capital we create with any expansion of P\&T-related faculty activity, and critical of what work can then be less valued as capital, and which individuals may hold, or not, capital, including that on which I\&E activity is built upon and including the human-related capital of broad institutional relationships [93,94], interpersonal networks [95], interorganizational networks [96], prior lab-industry relationships [97], and the orientation of past mentors or advisors toward commercialization [66].

We must be cautious to protect against those with such past affordances serving as the only decisionmakers around I\&E in P\&T. Those often lead, support, and finance revisions and structures in academia (predominantly white and cis-male academics, often holding positivist worldviews, assuming social phenomena and organizational variables and changing strategies to be obvious and accurately measurable) [98]. Leaders thus plan programming, assuming certain inputs will beget obvious outputs for all faculty, irrespective of other relevant social factors. This is likely exacerbated by the belief that structures and practices (including those around professional advancement) are meritocratic, objective, and unbiased, all of which research shows begets additional biased behaviors [99-101]. Indeed a plethora of research cautions that those within an organizational majority have little incentive to identify underrepresented faculty realities, and allow their decision-making, and agency [102]. Keeping marginalized voices centered is vital for any efforts attempting systemic change in academia [103]. We too assert that adopting these perspectives can 
help to inform education leaders and faculty of the more helpful strategies, both inclusive and responsive to faculty realities. This may be especially helpful in considering a potential tension between neoliberal perspectives and practices and the needs and realities of marginalized members of society.

These concerns further implicate training around faculty I\&E, around its assessment and its performance, with these explicit concerns in mind and attended to. Our survey found training for evaluation of faculty I\&E in P\&T considerations, for both faculty and administrators, was practically nonexistent. Providing training in this area will be especially instrumental if more faculty become in need of peer review that can adequately evaluate this work, both within and across institutions. Importantly, we also see training across faculty and administrators instrumental for success in that a purely top-down approach is unlikely to be effective; a bi-directional approach to change is needed around most aspects of faculty P\&T.

Most of our survey respondents felt themselves capable of evaluating faculty I\&E in P\&T considerations (while not seeing others in the same light), potentially implicating bias in our sample (of those competent doing such), inaccuracies in perceptions of one's own or others' ability, or a mixture of these. We recommend institution-specific data-gathering to try to obtain the training that may be necessary, and for whom. During this, we recommend eliciting discipline- and unit-based information that may also help to drive specifics of the training around strategy of what I\&E may resemble and related flexibility of this, to what degree may it count, and how it may be seen in relation to other categories of faculty work (e.g., research, service, outreach, and teaching). Faculty and administrators may consider consulting academics at other institutions for insight. Faculty members and the committees at their institutions charged to find qualified peer reviewers will potentially need support to locate those who have experienced quality training in this arena and that are willing to provide peer review around I\&E activities.

Training for faculty and postdoctoral engagement in I\&E did seem to be happening at the institutions we received data from, but support and training for students' engagement in I\&E was very limited. Graduate students seemed particularly underserved in terms of I\&E training. Across institution types, scant training regarding faculty I\&E was noted. Considering the numerous advantages for students per I\&E engagement, and the evolving realities of the workforce requiring graduates to be solvers of society's social, scientific, and technical problems [104], this is an area for improvement across institutions.

\section{Conclusions-Implications into Actions}

The culture of academia will likely continue to evolve to be more accepting, and demanding, of faculty I\&E toward enhancing the public good and economies. While concerns for this push exist, and need further consideration, other benefits of faculty I\&E include those to faculty members, themselves, their institutions, and students. Yet key processes and structures around the evaluation of faculty I\&E, explicitly for faculty P\&T, may still be lagging. Personnel surveyed from 99 diverse US institutions of higher education indicated room for improvements in this area, specifically:

(1) Creation and implementation of practices and structures (including policy) to evaluate faculty I\&E in P\&T considerations, including I\&E work with students;

(2) Understanding of the realities and desires of faculty working across disciplines, the various forms that I\&E may take per differences in discipline-influenced scholarship, and the nuance of evaluating I\&E across ways of knowing and discipline-based cultures;

(3) Training those involved in P\&T decisions to evaluate faculty I\&E, including faculty and administrators; and

(4) Training faculty (especially from underrepresented groups) and students (undergraduates and graduate students alike) in participation in I\&E activities.

Although the sample in this exploratory study was admittedly small, we believe that, collectively, our results afford insight into realities of institutional commitments, policies, 
practices, and training (and not) for promoting I\&E in higher education. The personnel across US institutional types that we surveyed also expressed interest in working together to potentially attend to these needs, and to generally problematize and support evaluation of faculty I\&E in P\&T considerations. Several of the institutions we surveyed may offer models from others to emulate or learn from. Indeed, our results are hopeful toward realizing evaluation of faculty that aligns with the I\&E work that their institutions, and the larger society, are asking of them. The current P\&T system in the cultural field of academia is based on norms concerning faculty work, including legitimacy conferred by peers who act per history of institutional isomorphism. As such, "counting" of faculty I\&E in P\&T considerations for most institutions in the US will not be possible without a critical number of their institutional peers and those working at them, acting similarly.

Institutional isomorphism may help secure systemic innovation around this issue, assuming some institutions with enough prestige among academics, working in tandem, and providing templates for successful evaluations of faculty I\&E in P\&T considerations. In theory, a critical mass of institutions can expand and create the necessary shift to norms of perception, structures, and practices. Of the institutions who participated in our survey, seventy (70) indicated an interest in being part of the Promotion \& Tenure Innovation \& Entrepreneurship (PTIE) Coalition, an NSF-supported, non-binding alliance of institutions of higher education that share a common commitment to pursuing best practices for inclusively recognizing faculty I\&E impact through the reward structure at US universities. Currently, over 67 institutional members-strong, the coalition is attempting an ecosystem approach to transformation [105]. Via an interwoven network of change agents, the coalition intends to change a P\&T system by attending to deep-seated cultural norms, partially by using institutional isomorphism as an advantage.

Work of the coalition is already underway, with significant progress accomplished at a September 2020 Coalition Summit, hosted by Oregon State University. From this summit emerged recommendations (https:/ / ptie.org/ptie-recommendations/, accessed on 3 August 2021) that serve as a non-binding resolution and guides for coalition institutions to (1) attempt to revise P\&T structures (e.g., policies) and processes (e.g., the actual practices of those reviewing dossiers) at their institutions and, (2) collaborate with others in the coalition to realize the important structures and practices needed across institutions per the P\&T review norms in academia. Recognizing the limits of changing all norms in a cultural field of academia, the coalition's goal is not to overhaul the traditional mechanisms for evaluating faculty. Instead, it hopes to have faculty and leaders in academia better recognize I\&E in P\&T by "broadening the bar" of privileged faculty work [88]. See https:/ / ptie.org/ (accessed on 3 August 2021) for information on the coalition, as well as our specific recommendations for relevant stakeholders. See, also, our forthcoming publication that further describes this work [106].

Walking a "fine line" of attempting change within a system of strong and longlasting cultural norms is a potential place of tension for the coalition, one attempted to be addressed head-on via various coalition strategies, for instance attention to related equity and inclusion issues. Coalition efforts, and related successes and mis-steps, will be of interest to many; these will be tracked and studied. Our future research, with continued funding from the National Science Foundation, will document over time the development, work, challenges, and accomplishments of this coalition, as well as cases of affiliated institutions. In addition to studying the degree of success of the project writ large, our research team will continue to track the degree of relevant changes, and reasons for these, across the spectrum of US-types involved in the initiative, with their varying identities, needs, and stature among peers. We hope this can inform those attempting revisions to P\&T processes and structures, in general, and concerning faculty I\&E specifically. 
Author Contributions: J.B.-G. designed and supervised the study, contributed to the data analysis and interpretation, led writing/revising of the article, and helped secure study funding. C.L. contributed to collection, analysis, and display of data and contributed to writing/revising of the article. R.C. contributed to the design of study, revising/editing of the article, and led the securing of funding and oversaw the PTIE project. K.M. contributed to the design of study, editing of the article, and helped secure and manage study funding. H.C. contributed to analysis and display of data. J.K. helped to identify and review literature and references toward paper design. All authors have read and agreed to the published version of the manuscript.

Funding: This study was funded by the National Science Foundation (NSF) grant \# CNS-1936073 and Oregon State University. Any opinions, findings, and conclusions or recommendations expressed in this material are those of the authors and do not necessarily reflect the views of the National Science Foundation.

Institutional Review Board Statement: The study was conducted according to the guidelines of the Declaration of Helsinki, and approved by the Institutional Review Board of Oregon State University (protocol 2019-0327, approved 4 December 2019).

Informed Consent Statement: Informed consent was obtained from all subjects involved in the study.

Data Availability Statement: A detailed description of the format used for the work and the complete recommendations from the PTIE Coalition are publicly available in ScholarsArchive@OSU Open Access Repository.

Acknowledgments: We thank all participants for volunteering in this study as well as Brian Wall (Oregon State University), Irem Y. Tumer (Oregon State University), and Tuba Ozkan-Haller (Oregon State University) for their overall support of this PTIE effort as fellow organizers.

Conflicts of Interest: Authors declare that they have no competing interests.

\section{References}

1. Clark, J.H.C.; Murri, K.; Nijhawan, V.; Blackwell, C.T.; Overton, D.; Ingram, S. The Innovation Impact of U.S. Universities: Ranking and Policy Conclusions. 2020. Available online: https://gwbcenter.imgix.net/Publications/Resources/gwbi-universityimpact-report-ranks-exec-summary.pdf (accessed on 3 August 2021).

2. Mintz, S. Why Higher Education Will Change I Inside Higher Ed. High. Ed. Gamma MOOCS beyond 2010. Available online: https:/ / www.insidehighered.com/blogs/higher-ed-gamma/why-higher-education-will-change (accessed on 3 August 2021).

3. O'Meara, K. Inside the panopticon: Studying academic reward systems. In Higher Education: Handbook of Theory and Research; Smart, J.C., Paulsen, M.B., Eds.; Springer: New York, NY, USA, 2011; Volume 26.

4. Park, T. Do Faculty Members Get What They Deserve?: A Review of the Literature Surrounding the Determinants of Salary, Promotion and Tenure. J. Profr. 2011, 6, 28-47.

5. O'Meara, K.; Eatman, T.; Petersen, S. Advancing engaged scholarship in promotion and tenure: A roadmap and call for reform. Lib. Educ. 2015, 101, 52-57.

6. Klein, J.T. Interdisciplinarity and Complexity: An Evolving Relationship*. Available online: http://link.galegroup.com/apps/ doc/A140447622/AONE?sid=lms (accessed on 3 December 2019).

7. Durodoye, R.; Gumpertz, M.; Wilson, A.; Griffith, E.; Ahmad, S. Tenure and Promotion Outcomes at Four Large Land Grant Universities: Examining the Role of Gender, Race, and Academic Discipline. Res. High. Educ. 2020, 61, 628-651. [CrossRef]

8. U.S. Department of Education. Salary, Promotion, and Tenure Status of Minority and Women Faculty in U.S. Colleges and Universities; National Center for Education Statistics: Washington, DC, USA, 2000; p. 128.

9. Social Sciences Feminist Network Research Interest Group. The Burden of Invisible Work in Academia: Social Inequalities and Time Use in Five University Departments. Humboldt J. Soc. Relat. 2017, 39, 228-245.

10. Matthew, P.A. Written/Unwritten: Diversity and the Hidden Truths of Tenure; University of North Carolina Press: Chapel Hill, NC, USA, 2016; ISBN 978-1-4696-2773-1.

11. Gunier, L. The Tyranny of Meritocracy: Democratizing Higher Education in AMERICA; Beacon Press: Boston, MA, USA, 2015.

12. Ong, M.; Smith, J.M.; Ko, L.T. Counterspaces for women of color in STEM higher education: Marginal and central spaces for persistence and success. J. Res. Sci. Teach. 2017, 55, 206-245. [CrossRef]

13. Kolavalli, C. Strengthening knowledge creation and research in entrepreneurship: Inclusion matters. SSRN Electron. J. 2021, 3793768. [CrossRef]

14. Zambrana, R.E.; Wingfield, A.H.; Lapeyrouse, L.M.; Dávila, B.A.; Hoagland, T.L.; Valdez, R.B. Blatant, subtle, and insidious: URM faculty perceptions of discriminatory practices in predominantly white institutions. Sociol. Inq. 2017, 87, 207-232. [CrossRef]

15. Schimanski, L.A.; Alperin, J.P. The evaluation of scholarship in academic promotion and tenure processes: Past, present, and future. F1000Research 2018, 7. [CrossRef] 
16. Fisher, K.; Sitomer, A.; Bouwma-Gearhart, J.; Koretsky, M. Using social network analysis to develop relational expertise for an instructional change initiative. Int. J. STEM Educ. 2019, 6, 17. [CrossRef]

17. Mendoza, P.; Ocal, S.D.; Wang, Z.; Zhou, E. Faculty norms and university/industry linkages in STEMM. Stud. High. Educ. 2020, 45, 1474-1487. [CrossRef]

18. Genshaft, J.; Wickert, J.; Gray-Little, B.; Hanson, K.; Marchase, R.; Schiffer, P.E.; Tanner, R.M. Consideration of technology transfer in tenure and promotion. Technol. Innov. 2016, 17, 197-204. [CrossRef]

19. Bouwma-Gearhart, J. Teaching Professional Development of Science and Engineering Professors at a Research-Extensive University: Motivations, Meaningfulness, Obstacles, and Effects; University of Wisconsin-Madison: Madison, WI, USA, 2008.

20. Bouwma-Gearhart, J.; Sitomer, A.; Fisher, K.; Smith, C.; Koretsky, M. Studying organizational change: Rigorous attention to complex systems via a multi-theoretical research model. In Proceedings of the 2016 ASEE Annual Conference \& Exposition Proceedings, New Orleans, LO, USA, 26 June 2016; p. 25945.

21. Bouwma-Gearhart, J.; Carter, R.; Mundorff, K. A call for promoting faculty innovation \& entrepreneurship. Chg Mag. High. Learn. 2021, 53, 18-24.

22. Sheridan, J.; Savoy, J.N.; Kaatz, A.; Lee, Y.-G.; Filut, A.; Carnes, M. Write more articles, get more grants: The impact of department climate on faculty research productivity. J. Womens Health 2017, 26, 587-596. [CrossRef]

23. Niles, M.T.; Schimanski, L.A.; McKiernan, E.C.; Alperin, J.P. Why we publish where we do: Faculty publishing values and their relationship to review, promotion and tenure expectations. PLOS ONE 2020, 15, e0228914. [CrossRef]

24. Kezar, A.; Lester, J.; Carducci, R.; Gallant, T.B.; McGavin, M.C. Where are the faculty leaders? Strategies and advice for reversing current trends. Lib. Educ. 2007, 93, 14-21.

25. Cora-Bramble, D.; Zhang, K.; Castillo-Page, L. Minority faculty members' resilience and academic productivity: Are they related? Acad. Med. 2010, 85, 1492-1498. [CrossRef] [PubMed]

26. DiMaggio, P.J.; Powell, W.W. The iron cage revisited: Institutional isomorphism and collective rationality in organizational fields. Am. Sociol. Rev. 1983, 48, 147. [CrossRef]

27. Bourdieu, P.; Nice, R. Distinction: A Social Critique of the Judgement of Taste; Taylor \& Francis Group: London, UK, 2010; ISBN 978-1-135-87316-5.

28. Stensaker, B.; Dahl Norgard, J. Innovation and isomorphism: A case-study of university identity struggle 1969-1999. High. Educ. 2001, 42, 473-492. [CrossRef]

29. Sahlin, K.; Wedlin, L. Circulating ideas: Imitation, translation and editing. In The SAGE Handbook of Organizational Institutionalism; Greenwood, R., Oliver, C., Suddaby, R., Sahlin-Andersson, K., Eds.; SAGE: Thousand Oaks, CA, USA, 2008; pp. 218-242. ISBN 978-1-4739-7114-1.

30. Klein, J.T.; Falk-Krzesinski, H.J. Interdisciplinary and collaborative work: Framing promotion and tenure practices and policies. Res. Policy 2017, 46, 1055-1061. [CrossRef]

31. Calás, M.B.; Smircich, L.; Bourne, K.A. Extending the boundaries: Reframing "entrepreneurship as social change" through feminist perspectives. Acad. Manag. Rev. 2009, 34, 552-569. [CrossRef]

32. Slaughter, S.; Rhoades, G.; Fainholc, B. Academic capitalism and the new economy: Markets, state, and higher education. Can. J. High. Educ. 2005, 35, 127.

33. McClure, K.R. Building the innovative and entrepreneurial university: An institutional case study of administrative academic capitalism. J. High. Educ. 2016, 87, 516-543. [CrossRef]

34. Rooksby, J.H.; Pusser, B. Learning to litigate: University patents in the knowledge economy. Acad. Capital. Age Glob. 2014, 2014, 74-93.

35. McDevitt, V.; Mendez-Hinds, J.; Winwood, D.; Nijhawan, V.; Sherer, T.; Ritter, J.; Sanberg, P. More than money: The exponential impact of academic technology transfer. Technol. Innov. 2014, 16, 75-84. [CrossRef] [PubMed]

36. Stevens, A.J.; Johnson, G.A.; Sanberg, P.R. The role of patents and commercialization in the tenure and promotion process. Technol. Innov. 2011, 13, 241-248. [CrossRef]

37. Gonzales, L.D.; Núñez, A.M. The ranking regime and the production of knowledge: Implications for academia. Educ. Policy Anal. Arch. 2014, 22, 31.

38. Fechner, H.; Shapanka, M.S. Closing diversity gaps in innovation: Gender, race, and income disparities in patenting and commercialization of inventions. Technol. Innov. 2018, 19, 727-734. [CrossRef]

39. Beaudry, C.; Lariviere, V. Which gender gap? Factors affecting researchers' scientific impact in science and medicine. Res. Policy 2016, 45, 1790-1817. [CrossRef]

40. Comedy, Y.L.; Dougherty, E.L. Breaking barriers: Female inventors blazing a path forward. Technol. Innov. 2018, 19, 751-758. [CrossRef]

41. Couch, S.; Estabrooks, L.B.; Skukauskaite, A. Addressing the gender gap among patent holders through invention education policies. Technol. Innov. 2018, 19, 735-749. [CrossRef]

42. Ding, W.W.; Murray, F.; Stuart, T.E. Gender differences in patenting in the academic life sciences. Science 2006, 313, 665-667. [CrossRef] [PubMed] 
43. National Research Council. Gender Differences at Critical Transitions in the Careers of Science, Engineering, and Mathematics Faculty; The National Academies of Sciences, Engineering, \& Medicine: Washington, DC, USA, 2010; ISBN 978-0-309-11463-9.

44. National Academies of Sciences, Engineering, \& Medicine. Promising Practices for Addressing the Underrepresentation of Women in Science, Engineering, and Medicine: Opening Doors; The National Academies of Sciences, Engineering, \& Medicine: Washington, DC, USA, 2020; ISBN 978-0-309-49824-1.

45. National Commission on Innovation \& Competitiveness Frontiers. Competing in the Next Economy: The New Age of Innovation; Compete Council on Competitiveness: Washington, DC, USA, 2020.

46. Hunt, V.; Prince, S.; Dixon-Fyle, S.; Yee, L. Delivering through Diversity; McKinsey \& Company: New York, NY, USA, $2018 ;$ p. 42.

47. Demirkan, H.; Spohrer, J. T-shaped innovators: Identifying the right talent to support service innovation. Res. Technol. Manag. 2015, 58, 12-15. [CrossRef]

48. Kuratko, D.F. The emergence of entrepreneurship education: Development, trends, and challenges. Entrep. Theory Pract. 2005, 29, 577-597. [CrossRef]

49. Bouwma-Gearhart, J.; Choi, Y.; Lenhart, C.; Villanueva, I.; Nadelson, L.; Soto, E. Undergraduate students becoming engineers: The affordances of university-based makerspaces. Sustainability 2021, 13, 1670. [CrossRef]

50. Hora, M.; Newman, R.; Hemp, R.; Brandon, J.; Wu, Y. Reframing student employability: From commodifying the self to supporting student, worker, and societal well-being. Change Mag. High. Learn. 2020, 52, 37-45. [CrossRef]

51. Lenhart, C.; Bouwma-Gearhart, J.; Keszler, D.; Giordan, J.; Carter, R.; Dolgos, M. STEM graduate students' development at the intersection of research, leadership, and innovation. J. Coll. Sci. Teach. 2021, in press.

52. National Research Council. Enhancing the Effectiveness of Team Science; National Academies Press: Washington, DC, USA, 2015; ISBN 978-0-309-31683-5.

53. Haltiwanger, J.; Jarmin, R.S.; Miranda, J. Who creates jobs? Small versus large versus young. Rev. Econ. Stat. 2013, 95, 347-361. [CrossRef]

54. Hayter, C.S.; Lubynsky, R.; Maroulis, S. Who is the academic entrepreneur? The role of graduate students in the development of university spinoffs. J. Technol. Transf. 2017, 42, 1237-1254. [CrossRef]

55. Lautz, L.; Mccay, D.; Driscoll, C.; Glas, R.; Gutchess, K.; Johnson, A.; Millard, G. Preparing graduate students for STEM careers outside academia. Eos 2018, 99. [CrossRef]

56. NSF Survey of Doctorate Recipients. Available online: https://www.nsf.gov/statistics/srvydoctoratework/ (accessed on 17 April 2020).

57. Sanberg, P.R.; Gharib, M.; Harker, P.T.; Kaler, E.W.; Marchase, R.B.; Sands, T.D.; Arshadi, N.; Sarkar, S. Changing the academic culture: Valuing patents and commercialization toward tenure and career advancement. Proc. Natl. Acad. Sci. USA 2014, 111, 6542-6547. [CrossRef]

58. Mendoza, P.; Berger, J.B. Academic capitalism and academic culture: A case study. Educ. Policy Anal. Arch. 2008, 16, 23. [CrossRef]

59. Etzkowitz, H.; Leydesdorff, L. The Triple Helix-University-industry-government relations: A laboratory for knowledge based economic development. EASST Rev. 1995, 14, 14-19.

60. Anderson, M.S.; Ronning, E.A.; Vries, R.D.; Martinson, B.C. Extending the Mertonian norms: Scientists' subscription to norms of research. J. High. Educ. 2010, 81, 366-393. [CrossRef]

61. Lach, S.; Schankerman, M. Incentives and invention in universities. RAND J. Econ. 2008, 39, 403-433. [CrossRef]

62. Siegel, D.S.; Waldman, D.A.; Atwater, L.E.; Link, A.N. Commercial knowledge transfers from universities to firms: Improving the effectiveness of university-industry collaboration. J. High Technol. Manag. Res. 2003, 14, 111-133. [CrossRef]

63. Renault, C. Academic capitalism and university incentives for faculty entrepreneurship. J. Technol. Transf. 2006, 31, 227-239. [CrossRef]

64. Gumport, P.J. Universities and knowledge: Restructuring the city of intellect. Pek. Univ. Educ. Rev 2004, 4, 54-65.

65. Shane, S. Encouraging university entrepreneurship? The effect of the Bayh-Dole Act on university patenting in the United States. J. Bus. Ventur. 2004, 19, 127-151. [CrossRef]

66. Azoulay, P.; Ding, W.; Stuart, T. The impact of academic patenting on the rate, quality and direction of (public) research output. J. Ind. Econ. 2009, 57, 637-676. [CrossRef]

67. Mendoza, P. The Role of Context in Academic Capitalism: The Industry-Friendly Department Case. J. High. Educ. 2012, 83, 26-48. [CrossRef]

68. Welsh, R.; Glenna, L.; Lacy, W.; Biscotti, D. Close enough but not too far: Assessing the effects of university-industry research relationships and the rise of academic capitalism. Res. Policy 2008, 37, 1854-1864. [CrossRef]

69. Merton, R.K. The Sociology of Science: Theoretical and Empirical Investigations; University of Chicago Press: Chicago, IL, USA, 1973; ISBN 978-0-226-52092-6.

70. Macuare, K.; Kubisen, S. Highlights from the fifth annual conference of the national academy of inventors. Technol. Innov. 2017, 18, 229-233. [CrossRef]

71. Zarya, V. Female Founders Got 2\% of Venture Capital Dollars in 2017. Fortune, 31 January 2018.

72. Howe, S.A.; Juhas, M.C.; Herbers, J.M. Academic Women: Overlooked Entrepreneurs. Available online: https://www.aacu.org/ publications-research/periodicals/academic-women-overlooked-entrepreneurs (accessed on 20 July 2021).

73. Stephan, P.E.; El-Ganainy, A. The entrepreneurial puzzle: Explaining the gender gap. J. Technol. Transf. 2007, 32, 475-487. [CrossRef] 
74. Nelson, T. The Academic Entrepreneurship of Women Faculty in STEM: A Meta-Synthesis; ARC Network: A STEM Equity Brain Trust. 2020. Available online: https:/ / equityinstem.org/wp-content/uploads/Nelson-VVS.pdf (accessed on 3 August 2021).

75. Blume-Kohout, M.E. Understanding the Gender Gap In STEM Fields Entrepreneurship; U.S. Small Business Administration Office of Advocacy: Washington, DC, USA, 2014.

76. Bouwma-Gearhart, J.; Lenz, A.; Ivanovitch, J. The interplay of postsecondary science educators' problems of practice and competencies: Informing better intervention designs. J. Biol. Educ. 2018, 52, 1-13. [CrossRef]

77. Bouwma-Gearhart, J.; Adumat, S. Fostering successful interdisciplinary postsecondary faculty collaborations. Int. J. Univ. Teach. Fac. Dev. 2011, 53, 207.

78. Bouwma-Gearhart, J.; Collins, J. What We Know About Data Driven Decision-Making In Higher Education: Informing Educational Policy and Practice. In Proceedings of the International Academic Conferences, Madrid, Spain, 6-9 October 2015; International Institute of Social and Economic Sciences: Florence, Italy, 2015.

79. Miller, L. A Theoretical Framework for Value Creation: A Multidimensional Strategy/Model for Improving Social Economic Performance. J. Creat. Value 2016, 2, 257-267. [CrossRef]

80. Weber, M. The Theory of Social and Economic Organization, 1st ed.; Oxford University Press: New York, NY, USA, 1947.

81. Becker, G.S. Human Capital: A Theoretical and Empirical Analysis with Special Reference to Education; University of Chicago Press: Chicago, IL, USA, 2002.

82. Gillies, D. Human Capital Theory in Education. In Encyclopedia of Educational Philosophy and Theory; Peters, M., Ed.; Springer: Singapore, 2015; pp. 1-5. ISBN 978-981-287-532-7.

83. Indiana University Center for Postsecondary Research. Carnegie Classification of Institutions of Higher Education. 2017. Available online: https: / / carnegieclassifications.iu.edu/ (accessed on 20 July 2021).

84. Cochran, W.G. Sampling Techniques, 3rd ed.; Wiley: Hoboken, NJ, USA, 2007.

85. Moore, D.S.; Notz, W.I.; Notz, W. Statistics: Concepts and Controversies; Macmillan: New York, NY, USA, 2006.

86. Sousa, V.D.; Zauszniewski, J.A.; Musil, C.M. How to determine whether a convenience sample represents the population. Appl. Nurs. Res. ANR 2004, 17, 130-133.

87. Herbers, J.M.; Metcalf, H.E.; Williams, R.L. Identity-Based Harassment; Emerging Research Workshop: Naperville, IL, USA, 2019.

88. National Academies of Science, Engineering, and Medicine. Re-Envisioning Promotion and Advancement for STEM Faculty Aligning Incentives with Values. Available online: https://www.nationalacademies.org/event/10-17-2019/re-envisioningpromotion-and-advancement-for-stem-faculty-aligning-incentives-with-values (accessed on 17 April 2020).

89. Marx, M.; Hsu, D.H. Revisiting the Entrepreneurial Commercialization of Academic Science: Evidence from "Twin" Discoveries; Working Paper Series; National Bureau of Economic Research: Cambridge, MA, USA, 2020.

90. Wang, Y.; Yang, Z.; Liu, L.; Wang, X. Gender bias in patenting process. J. Informetr. 2020, 14, 101046. [CrossRef]

91. Rosser, S.V. The gender gap in patenting: Is technology transfer a feminist issue? NWSA J. 2009, 21, 65-84.

92. Intemann, K. Why diversity matters: Understanding and applying the diversity component of the national science foundation's broader impacts criterion. Soc. Epistemol. 2009, 23, 249-266. [CrossRef]

93. Leydesdorff, L.; Etzkowitz, H. Emergence of a triple helix of university-industry-government relations. Sci. Public Policy 1996, 23, 279-286. [CrossRef]

94. Berman, E.P. Creating the Market University; Princeton University Press: Princeton, NJ, USA, 2012; ISBN 978-0-691-14708-6.

95. Murray, F. The role of academic inventors in entrepreneurial firms: Sharing the laboratory life. Res. Policy 2004, 33, 643-659. [CrossRef]

96. Powell, W.W.; White, D.R.; Koput, K.W.; Owen-Smith, J. Network dynamics and field evolution: The growth of interorganizational collaboration in the life sciences. Am. J. Sociol. 2005, 110, 1132-1205. [CrossRef]

97. Evans, J.A. Industry induces academic science to know less about more. Am. J. Sociol. 2010, 116, 389-452. [CrossRef]

98. Bess, J.L.; Dee, J.R. Bridging the Divide between Faculty and Administration: A Guide to Understanding Conflict in the Academy; Routledge: London, UK, 2014.

99. Moss-Racusin, C.A.; Dovidio, J.F.; Brescoll, V.L.; Graham, M.J.; Handelsman, J. Science faculty's subtle gender biases favor male students. Proc. Natl. Acad. Sci. USA 2012, 109, 16474-16479. [CrossRef]

100. Uhlmann, E.L.; Cohen, G.L. Constructed criteria: Redefining merit to justify discrimination. Psychol. Sci. 2005, 16, 474-480. [PubMed]

101. Uhlmann, E.L.; Cohen, G.L. "I think it, therefore it's true": Effects of self-perceived objectivity on hiring discrimination. Organ. Behav. Hum. Decis. Process. 2007, 104, 207-223. [CrossRef]

102. Aguirre, A., Jr. Diversity as interest-convergence in academia: A critical race theory story. Soc. Identities 2010, 16, 763-774. [CrossRef]

103. Quan, G.M.; Corbo, J.C.; Finkelstein, N.D.; Pawlak, A.; Falkenberg, K.; Geanious, C.; Ngai, C.; Smith, C.; Wise, S.; Pilgrim, M.E.; et al. Designing for institutional transformation: Six principles for department-level interventions. Phys. Rev. Phys. Educ. Res. 2019, 15, 010141. [CrossRef]

104. Hewitt, K.; Bouwma-Gearhart, J.; Kitada, H.; Mason, R.; Kayes, L. Introductory biology in social context: The effects of an issues-based laboratory course on biology student motivation. CBE-Life Sci. Educ. 2019, 18, ar30. [CrossRef] 
105. Dinwoodie, D.L.; Criswell, C.; Tallman, R.; Wilburn, P.; Petrie, N.; Quinn, L.; McGuire, J.; Campbell, M.; McEvoy, L. Transformational Change: An Ecosystem Approach. Center for Creative Leadership. 2014. Available online: https://nature-wise.nl/wpcontent/uploads/2014/11/TransformationalChange.pdf (accessed on 20 July 2021).

106. Carter, R.; Mundorff, K.; Risien, J.; Bouwma-Gearhart, J.; Bratsch-Prince, D.; Brown, S.; Campbell, A.; Hartman, J.; Hasemann, C.; Hollenbeck, P.; et al. Inclusive recognition of innovation \& entrepreneurship impact. Science 2021, in press. 